Proceedings of the Prehistoric Society 85, 2019, pp. 83-114 (C) The Prehistoric Society. This is an Open Access article, distributed under the terms of the Creative Commons Attribution licence (http://creativecommons.org/ licenses/by/4.0/), which permits unrestricted re-use, distribution, and reproduction in any medium, provided the original work is properly cited.

doi:10.1017/ppr.2019.2 First published online 14 August 2019

\title{
Calling Time on Oronsay: Revising Settlement Models Around the Mesolithic-Neolithic Transition in Western Scotland, New Evidence from Port Lobh, Colonsay
}

\author{
By NYREE FINLAY ${ }^{1}$, RUBY CERÓN-CARRASCO ${ }^{2}$, RUPERT HOUSLEY ${ }^{3}$, JEREMY HUGGETT ${ }^{1}$, W. GRAHAM JARDINE ${ }^{4}$, \\ SUSAN RAMSAY ${ }^{4}$, CATHERINE SMITH ${ }^{5}$, DENE WRIGHT ${ }^{1}$, JULIAN AUGLEY ${ }^{6}$ and PETER J. WRIGHT ${ }^{6}$
}

For over 120 years, the shell middens of western Scotland and the series of open-air sites on Oronsay have been the focus of debate in European Mesolithic studies. This paper challenges the significance of Oronsay in light of results from the geophysical survey and test-excavation of a new limpet and periwinkle shell midden dated to the late 5th or start of the 4th millennium cal $B C$ at Port Lobh, Colonsay that offers fresh evidence to re-evaluate critically the role of Oronsay and coastal resources in island settlement models ahead of the Mesolithic-Neolithic transition. Test excavations recovered a marine molluscan assemblage dominated by limpet and periwinkle shells together with crab, sea urchin, a fishbone assemblage composed mainly of Gadidae, some identifiable bird and mammal bone, carbonised macroplant remains, and pumice as well as a bipolar lithic assemblage and coarse stone implements. Novel seasonality studies of saithe otolith thin-sections suggest wintertime tidal fishing practices. At least two activity events may be discerned, dating from the late 5th millennium cal BC. The midden could represent a small number of rapidly deposited assemblages or maybe the result of stocastic events within a more extended timeframe. We argue that alternative research questions are needed to advance long-standing debates about seasonal interisland mobility versus island sedentism that look beyond Oronsay to better understand later Mesolithic occupation patterns and the formation and date of Oronsay middens. We propose alternative methodological strategies to aid identification of contemporaneous sites using geophysical techniques and lithic technological signatures.

Keywords: Mesolithic-Neolithic transition, settlement history, geophysical survey, flint, midden, marine molluscs, saithe otoliths, Oronsay, Colonsay, radiocarbon dating

\section{CALLING TIME ON ORONSAY}

${ }^{1}$ Archaeology, School of Humanities/Sgoil nan Daonnachdan, University of Glasgow, Glasgow G12 8QQ, Scotland Nyree. Finlay@glasgow.ac.uk

${ }^{2}$ Conservation Directorate, Historic Environment Scotland I Àrainneachd Eachdraidheil AlbaLongmore House, Salisbury Place, Edinburgh, EH9 1SH. ruby.ceron-carrasco@hes.scot ${ }^{3}$ Department of Geography, Queens Building, Royal Holloway University of London, Egham, Surrey TW20 0EX. Rupert.Housley@rhul.ac.uk

${ }^{4}$ Brownwell Cottage, Standrigg Road, Wallacestone, Falkirk. FK2 0EB. susan.ramsays@googlemail.com

${ }^{5}$ Alder Archaeology Ltd, 55 South Methven Street, Perth, PH1 5NX. csmith@alderarchaeology.co.uk

${ }^{6}$ Marine Scotland Science, 375 Victoria Road Aberdeen, P.J.Wright@marlab.ac.uk; jules.augley@gmail.com
The prehistoric shell midden sites on the small island of Oronsay, off the coast of Colonsay (Scottish Inner Hebrides), have been the subject of much debate since the late 19th century (Anderson 1898). The first of their kind to be excavated, these sites contributed to definitions of an 'Obanian' maritime cultural complex based on shell-rich deposits from cave and rockshelters around the west coast of mainland Scotland that have dominated discussions of the Scottish Mesolithic (Bishop 1914; Lacaille 1954; Bonsall 1997; Finlay et al. 2004; Saville 2004; WickhamJones 2009). Much of the significance attributed to the Oronsay middens has resulted from their size, 
density, apparent uniqueness, and their exceptional organic preservation in a regional context. In the 1970s, Paul Mellars directed excavations at five Oronsay middens sites which were approached from an ecological perspective (Mellars 1987). On the basis of seasonality data from measuring saithe otolith lengths (Mellars \& Wilkinson 1980), year-round occupation of the small $4 \mathrm{~km}^{2}$ island was posited with movement between the various midden locations at different times of the year (Mellars 1978; 1987; $2004,117)$. In contrast to this model of Oronsay sedentism, it has also been argued that the shell middens resulted from short-term and intermittent occupation by groups based primarily elsewhere, such as on the neighbouring islands of Colonsay, Jura, and Islay (eg, Mithen \& Finlayson 1991; Mithen 2000a). Stable isotope analysis of human remains from $\mathrm{Cnoc}$ Coig of individuals with extreme marine and others with mixed terrestrial dietary signatures have contributed another dimension to this debate and been used to support both models without clear resolution (Richard \& Mellars 1998; Milner \& Craig 2009; Charlton et al. 2016). Recent Bayesian analysis of radiocarbon dates from the Oronsay sites and new fieldwork at Storakaig, Islay (a lithic scatter site with terrestrial fauna) has produced evidence of contemporaneous regional occupation that overlaps with the earliest Neolithic in the region (Wicks et al. 2014; contra Mithen 2000a). Yet clear understandings of the role of Oronsay in inter-island settlement and subsistence models at this critical period still appear beyond grasp.

In this contribution we propose that current debate needs to move forward and away from these opposed positions and mobility versus sedentism models. This necessitates looking beyond Oronsay itself and recognising that some of the basic underlying evidential assumptions within these models demand critical re-appraisal in the light of recent studies. Through the application of new methodological strategies and targeted fieldwork to both identify and characterise shell midden deposits of this period we address issues of site identification and characterisation and we trial novel approaches to examine seasonality using otolith thin section data.

First, we present the results of the survey and test excavation of a new shell midden at Port Lobh on the west coast of Colonsay (Fig. 1), the first shell midden of this period to be identified and excavated on that island. Port Lobh challenges the unique status of the Oronsay sites. It offers new radiocarbon dates and adds further new information about the character of lifeways in the late 5th-early 4th millennia cal BC.

The fieldwork, undertaken in 2005-6, demonstrated the efficacy of close-interval geophysical techniques as a means of developing tools for the characterisation of gatherer-hunter type-sites of this type (Finlay \& McAllen 2009). This identified further, previously unknown, shell-rich deposits producing the first radiocarbon dated Iron Age occupation evidence on the island (Finlay et al. 2019).

Secondly, we present the results of various specialist studies and new single entity dating that highlights aspects of the depositional history of this shell midden. Thirdly, in the discussion section we challenge the unique status of the Oronsay middens through a better appreciation of their distinctive archaeological biographies in the recent past. Finally, we examine the wider implications of Port Lobh for investigating later Mesolithic resource use and the Mesolithic-Neolithic transition and conclude with a call to move on debate.

\section{SITE LOCATION AND DISCOVERY}

Port Lobh 1 is a mound (NR3573 9272) situated c. $150 \mathrm{~m}$ ESE of the modern Mean High Water Spring Tides (MHWS) shoreline (Fig. 1). It may be the place referred to as Drum Sligeach (McNeill 1910, 29). Located in rough pasture, it is now part of the island golf course, with a tee immediately beside the site. Rabbit activity and wind blow-out is obvious in the immediate area and is reported to have been much more extensive within living memory (J. McNeill, pers. comm.).

The mound is an elongated north-south oriented ovoid feature measuring c. $25 \mathrm{~m}$ (east-west) by c. $30 \mathrm{~m}$ (north-south) and is bisected by a farm track (Figs. $1 \& 2$ ). It lies between $12.8 \mathrm{~m}$ and $15.8 \mathrm{~m} \mathrm{OD,}$ close to the conjectural position of the Main Holocene Shoreline (Jardine 1987) and on the southern edge of what would most likely have been an extensive lagoon estuary in early prehistory, opening out to the sea in the sheltered bay at Port Lobh with accessible rocky shore with skerries beyond. Further work on landscape modelling and establishing a new sea-level curve for Colonsay and Oronsay is needed to better date and understand the site environment. The large rock masses of Turnigil and Carn Glas located a few hundred metres to the south-west, and rising to over $30-50 \mathrm{~m}$, today offer protection from prevailing 
N. Finlay et al. REVISING SETTLEMENT MODELS, MESOLITHIC-NEOLITHIC TRANSITION, W. SCOTLAND
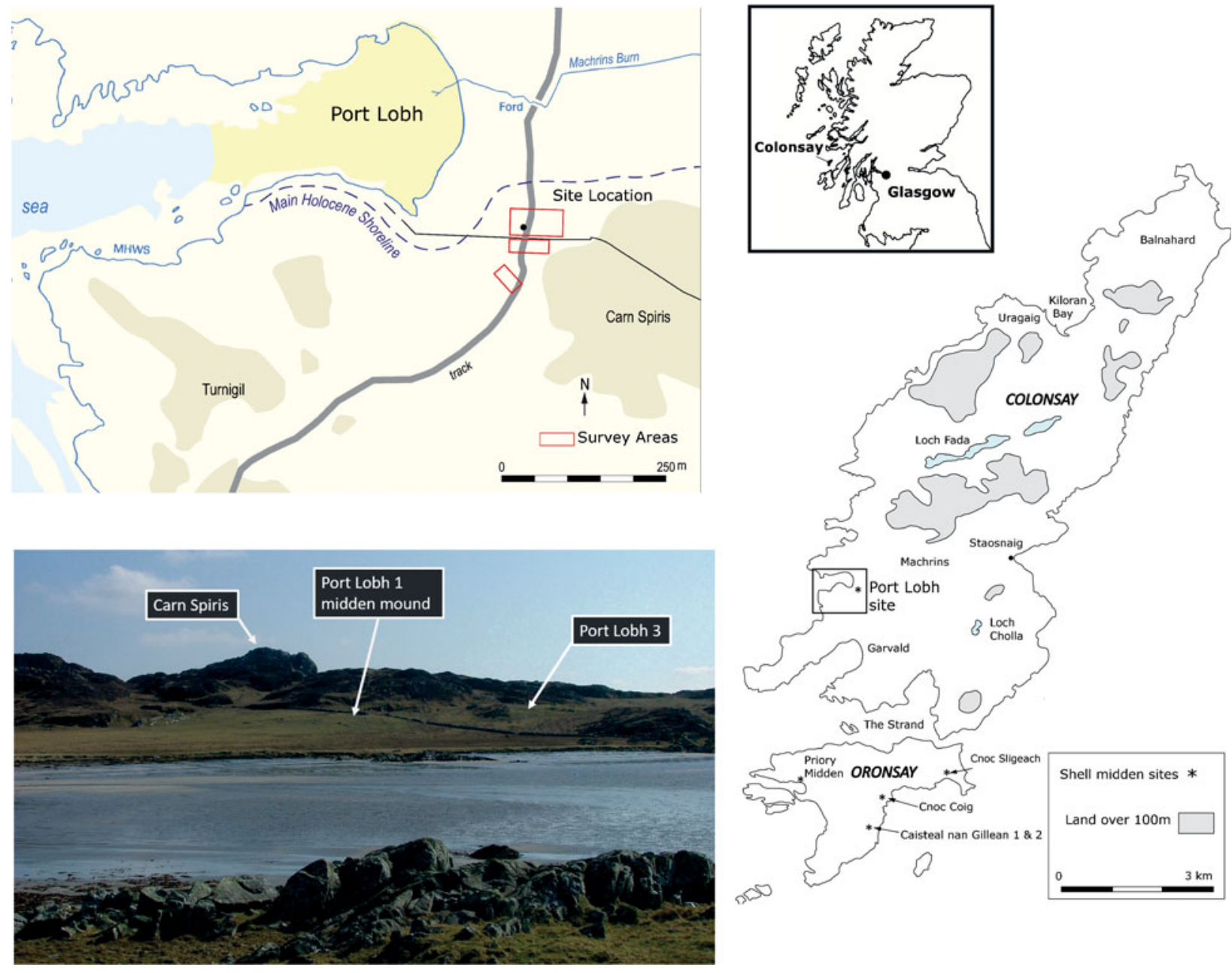

Fig. 1.

Port Lobh shell midden site location and landscape view from Dun Gallain. Contains OS data $\odot$ Crown copyright and database right 2018 Ordnance Survey (100025252)

winds. Freshwater is available in a stream immediately to the east. The gently rising topography below Carn Spiris would have provided suitable occupation areas with good visibility and easy access from the shore.

Port Lobh was first identified as a probable shell midden by the late W. Graham Jardine, during his research into Holocene sea levels (eg, Jardine 1987). He recovered various lithic artefacts at the site during annual visits between 1984-2003, along with fragmentary limpet and periwinkle shells. He identified several other prehistoric sites and other, as yet unexplored, mounds in the vicinity (Finlay \& Jardine 2015). Prior to this, the area to the north and north-east of Port Lobh has produced flint cores, a Bronze Age occupation site (Macleod \& Gordon
2006), and Norse burials (Ritchie 1981; Becket \& Batey 2013). Further east, at Machrins, blade and bipolar cores and a porcellanite stone axehead were recovered during field-walking (Mithen 2000c, 353).

\section{Geophysical survey}

One of the aims of the fieldwork was to develop geophysical survey for shell middens, building on a previous research pilot at Sand, Applecross (Finlay \& McAllen 2009; Finlay \& Crowther unpublished manuscript). The emphasis here was on the use of geophysical survey as a non-invasive shell midden characterisation tool in addition to its obvious value for site prospection. The survey used a combination 

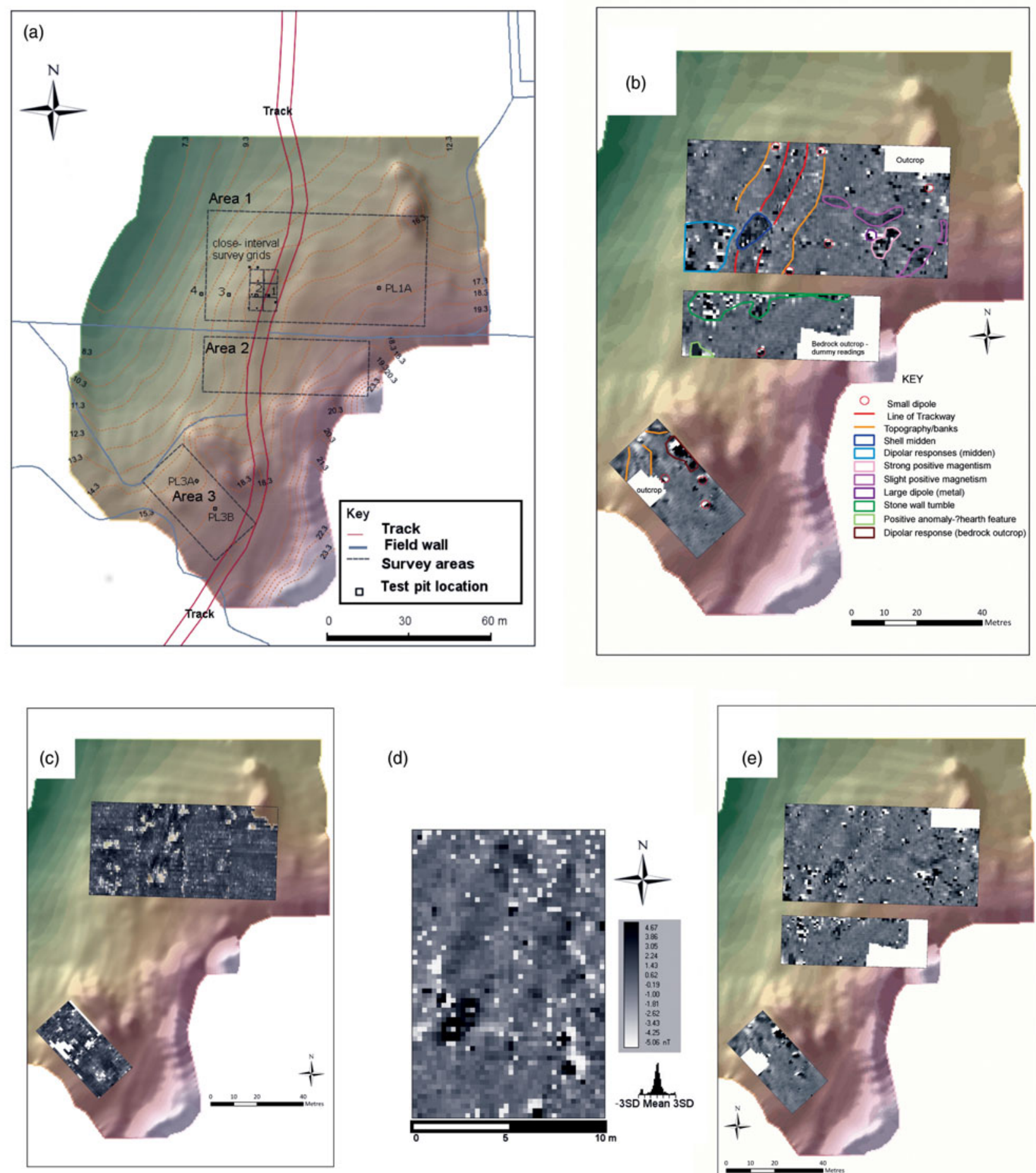

(d)

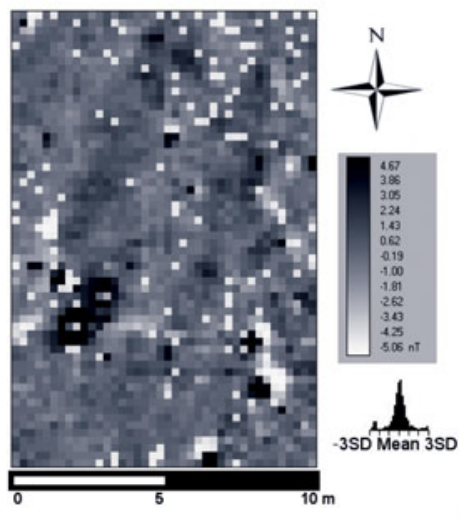

Fig. 2.

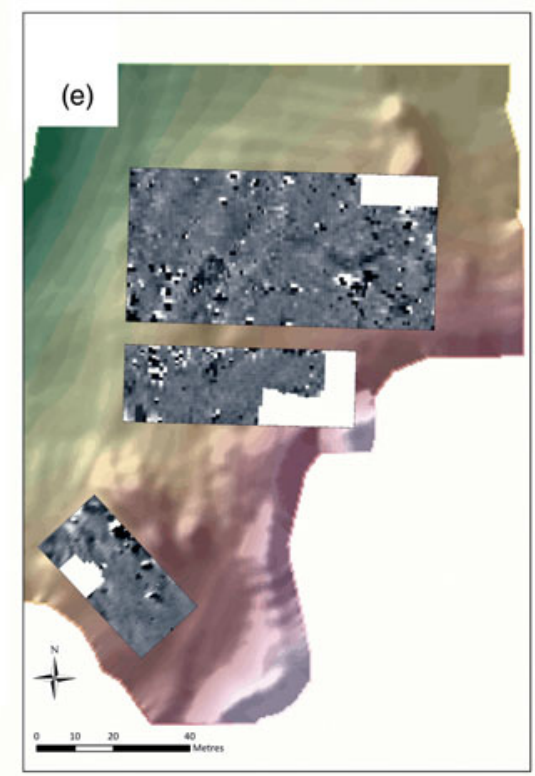

A. Topographic survey, geophysical survey areas and location of test-pits; B. Magnetometry survey interpretation; C. Resistivity survey processed data; D. Close-interval magnetometry processed data; E. Magnetometry unprocessed data. Contains OS data (C) Crown copyright and database right 2018 Ordnance Survey (100025252) 


\section{N. Finlay et al. REVISING SETTLEMENT MODELS, MESOLITHIC-NEOLITHIC TRANSITION, W. SCOTLAND}

of earth resistance, magnetometry, and fluxgate magnetometry over $5200 \mathrm{~m}^{2}$ in three survey areas (Fig. 2, A: 1-3) with further close-interval surveys over the midden mound itself. Earth resistance survey (using a Bartington RM15 with a zigzag $1 \mathrm{~m}$ traverse and $0.5 \mathrm{~m}$ sampling interval) results were strongly affected by sand upcast from rabbit burrowing and rock outcrops but, when interpreted together with the magnetometry results, buried shell rich midden deposits are visible (Fig. 2, C).

The Area 1 magnetometry survey (using a Bartington Grad 601 single sensor with the same operator and with a sensitivity of $1.0 \mathrm{nT}, \mathrm{n}-\mathrm{s}$ traverse) clearly show the shell midden as a discrete area characterised by very subtle negative readings (Fig. 2, B \& D). The dense area of shells has a more uniform magnetic response that may correlate with the depth of surviving deposits. There is a series of discrete individual dipolar responses which are more prevalent downslope from the midden that appear to be the result of enhanced magnetism from fire-cracked stone. Several other small dipoles across the survey area probably reflect later metal finds.

Similar subtle negative responses to those seen over the midden suggested the potential for further shell deposits in the east of the Area 1 survey area along with discrete areas of enhanced magnetism, suggestive of structures or other archaeological features. A small test-pit in this area (Fig. 2, A: PL1A) yielded discrete limpet and periwinkle shell deposits $c .0 .1-0.2 \mathrm{~m}$ thick, associated with occupation evidence (burnt ceramics and cattle bone) dated to 300-20 cal BC $(2445 \pm 35$ BP; SUERC-16342; Finlay et al. 2019). This is likely to relate to Iron Age domestic occupation for no substantial shell midden deposits were encountered. The date confirms the presence of later prehistoric settlement which may also have negatively impacted on earlier features and shell midden survival in the vicinity.

Geophysical survey was undertaken to the southwest of the main mound (Area 2), where extensive stone wall tumble was a factor along with remnants of metal fencing but no clear signatures suggestive of preserved shell midden were identified. Two positive magnetic anomalies in the south-west of the survey area close to a rock outcrop are suggestive of archaeological features, potentially of more recent date given their relative location. Geophysical survey was also undertaken in a sheltered hollowed area, Port Lobh 3 (NR35769264, Fig. 1; Fig. 2A: Area 3) behind a small rock outcrop where a burnt bipolar flint flake was found eroding from a rabbit burrow. The dipolar anomalies are associated with underlying bedrock in this area. Limited test-pitting found a further bipolar flint flake fragment (Fig. 2, A: PL3A) but no in situ shell midden deposits. Further bipolar lithic finds have since been noted from this general area (D. Jardine, pers. comm.).

\section{Excavation results}

Large open-area excavation of shell middens can be challenging, given stratigraphic complexity combined with the demands of post-excavation processing and analysis (Mellars 1987; Sloan 1988; Hardy \& Wickham-Jones 2009). At Port Lobh large scale excavation was impractical due to current land use combined with extensive rabbit burrows. The fieldwork strategy was therefore to undertake small-scale excavation in order to profile and evaluate the preservation condition of surviving archaeological deposits and enable site characterisation by obtaining samples suitable for analysis and radiocarbon dating.

Over the main mound site, three $1 \mathrm{~m}^{2}$ test pits (Test Pits 2-4) and three $0.5 \mathrm{~m}^{2}$ pits $(1,12,13)$ were hand excavated. Eight $0.25 \mathrm{~m}^{2}$ sondages were dug only to the surface of the midden layer (where present) and at a naturally eroding section face (Fig. 3). These were used to determine the spatial extent of the shell midden deposits and the associated stratigraphy downslope to the west and north.

The shell midden rested on yellow marine sand and appears to have been covered by wind-blown sand deposits that were still extant to the east but largely eroded away from the mound surface itself. Situated c. $0.2 \mathrm{~m}$ or less below the modern turf, the midden has clearly suffered from truncation, erosion, and animal disturbance in the recent past. In the smaller sondages, where a shell-rich deposit was not encountered, a brown sandy-silt layer with infrequent limpet and periwinkle shells was noted or topsoil came directly down onto sand.

Test Pit 1: Turf and topsoil layer overlay a truncated midden deposit: a golden sand deposit with frequent shells (003) which was 0.05-0.08 m thick. Under this was a dense shell midden deposit (007) which was $0.08 \mathrm{~m}$ thick and composed predominately of limpets with frequent periwinkles. It thinned out towards the eastern track-side and potential tip lines were visible in the west section (Fig. 3). Finds comprise a flint bipolar 


\section{Area A}

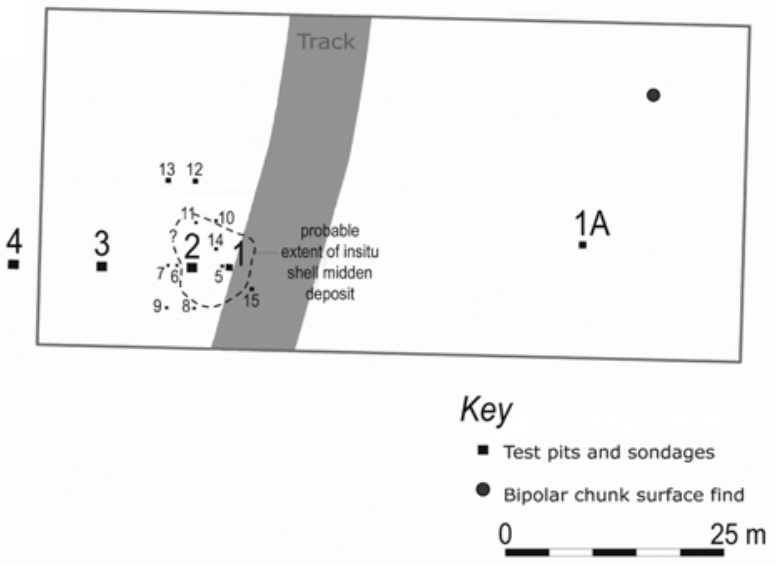

\section{East facing section of Test Pit 1}

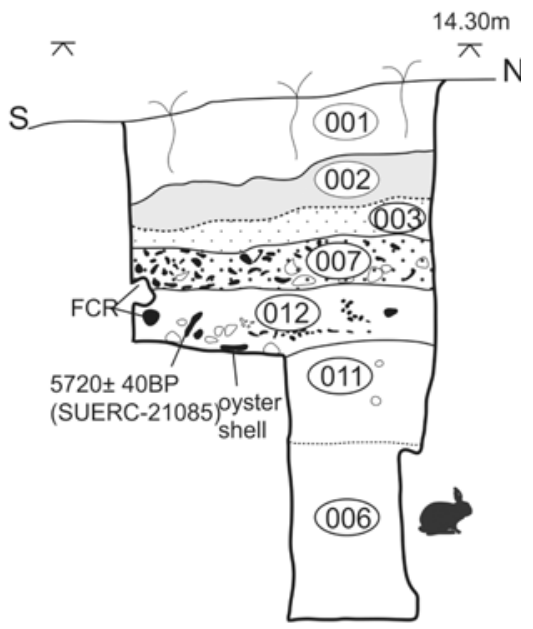

South facing section of Test Pit 2

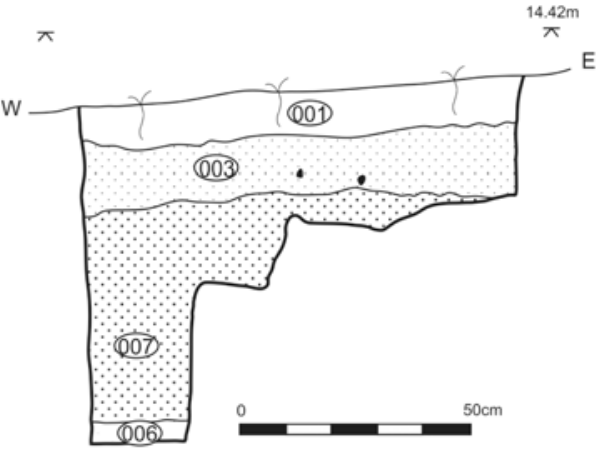

East facing section of Test Pit 2
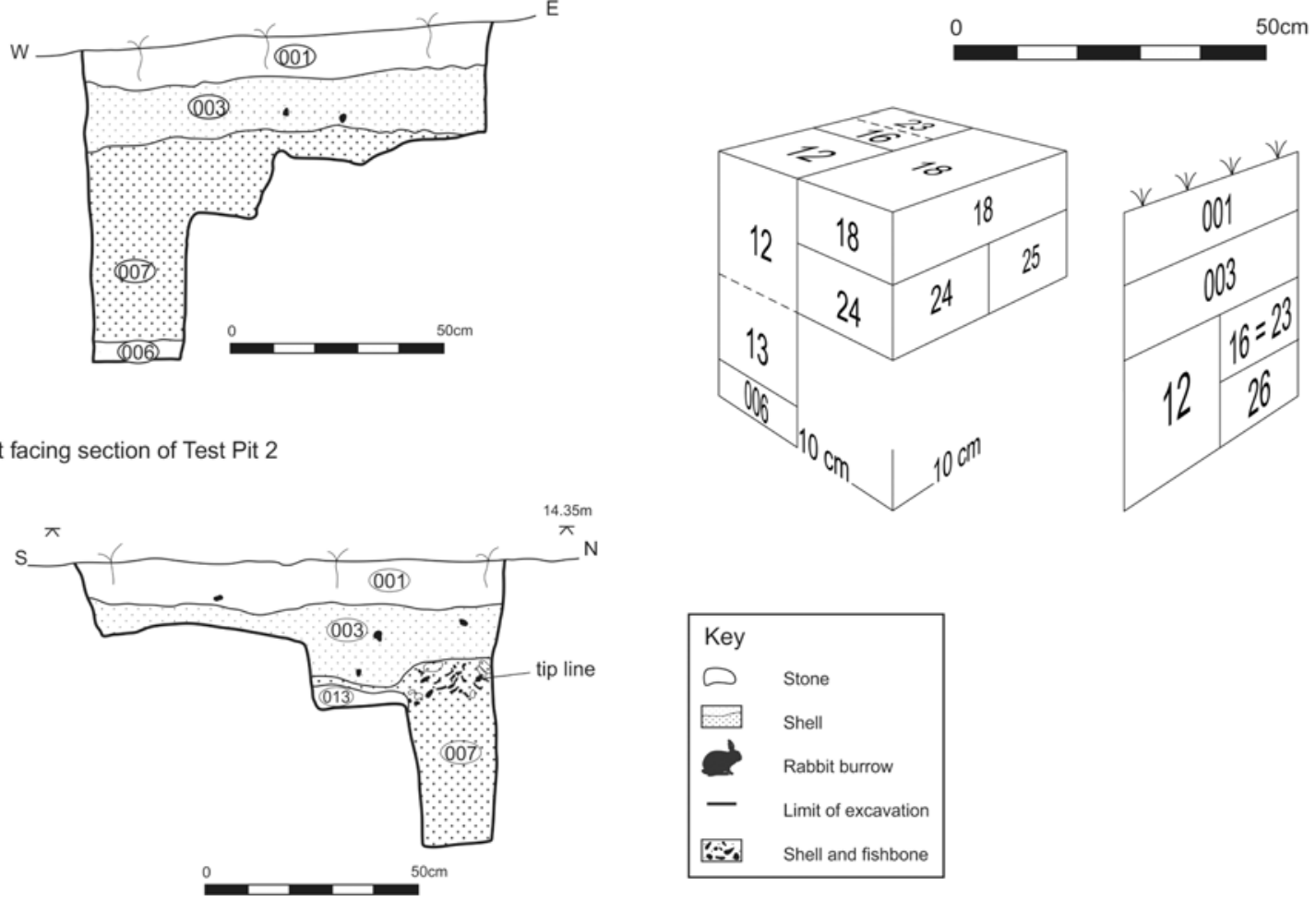

Fig. 3.

Test Pit sections (Test Pits $1 \& 2$ ) and schematic Test Pit 2 sampling strategy figure showing location of numbered samples for main midden deposit

core (SF13, Fig. 5.3) and three fire-cracked quartzite pebble fragments. Sieving of the southern half of the deposit for artefacts produced three further worked quartz chunks with evidence of bipolar reduction. Beneath this shell deposit was a medium brown sand layer (011) rich in unburnt cod fish bone including 


\section{N. Finlay et al. REVISING SETTLEMENT MODELS, MESOLITHIC-NEOLITHIC TRANSITION, W. SCOTLAND}

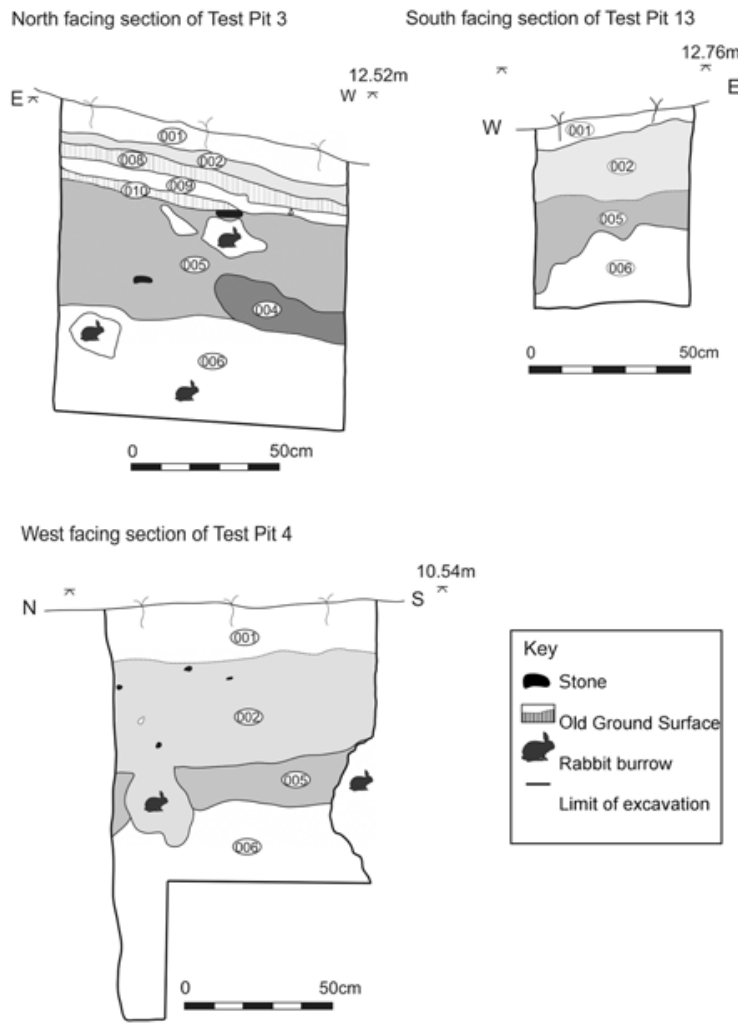

Fig. 4.

Test Pit sections (Test Pits 3, 4, \& 13)

vertebra, occasional marine shell, charcoal fragments, and a small flint flake (Fig. 5.5). A 0.04 m thick discontinuous lens made up mostly of limpet shells but also containing fish bone and fire-cracked rock was observed after excavation within this deposit in the west and north sections, and retrospectively labelled 012. Under this was a heavily rabbit-burrowed marine sand deposit (006).

Test Pit 2: The densest midden deposits were present within Test Pit 2. Here, turf and topsoil overlay a shell-rich light brown uncompacted sand deposit (003) interpreted as truncated midden material. The partial excavation of this deposit produced a flint bipolar flake, a quartzite flake, and two unmodified pumice pieces (see below). Underlying (003) was a blackish, more compacted shell midden deposit (007). Excavation of (007) was limited to the northern half of the test pit; here the shell layer was at least 0.45 $\mathrm{m}$ deep and overlay golden sand (006). A stone pebble tool (SF11; Fig. 6.3) was found lying horizontally c. $0.02 \mathrm{~m}$ from the base of the midden deposit.

The composition of the midden was predominately limpet and periwinkle shell contained within a loose sandy loam matrix. Many of the limpet shells were stacked within one another. The occasional oyster shell was present, with some razor and intact mussel shells but only the oyster survived processing complete. Fragments of carbonised hazelnut shell, crab claws, burnt and unburnt bone were also present. Other finds include flint flakes and several fire-cracked rocks (mostly quartzite pebble fragments). Although some potential horizontal layering was observed in section, no clearly differentiated depositional events were identified apart from an interdigitated sand lens (013) visible in the east facing section.

Test Pits 3 and 4: Two further $1 \mathrm{~m}^{2}$ test-pits were excavated: one midway down the lower slope (Test Pit 3, Fig. 4) and one near the base of the slope (Test Pit 4, Fig. 4). In Test Pit 3 at least two discontinuous old ground surface layers were identified in the upper part of the sequence $(008 \& 010)$ along with two discrete lenses of golden sand resulting from rabbit activity and/or wind-blown sand. Underlying this was a thick layer $(0.4 \mathrm{~m})$ of medium brown sandy soil (005), with infrequent limpet and periwinkle shells which formed a discontinuous layer truncated by rabbit burrows. A similar sequence of deposits was observed in Test Pit 4 . Here a medium brown sand deposit (005) was $0.18 \mathrm{~m}$ thick over yellow marine sand (006) which was in excess of a metre deep. No artefactual finds were recovered from either test-pit and rabbit disturbance was extensive.

North of the mound: No in situ shell-rich deposits were identified in two test pits north of the mound, rather a brown sandy-silt deposit (005), interpreted as denuded shell midden, occurs in this area. In Test Pit 12 marine shells were more numerous in the lower part of this layer; finds comprise a bipolar core and the distal end of a calcined otter bone. At the interface with the underlying marine sand, a red deer antler fragment and a piece of fire cracked rock were recovered. In adjacent Test Pit 13 potential spade cultivation traces are present, (Fig. 4), the finds comprise a small elongated pebble tool and two quartzite pieces. 


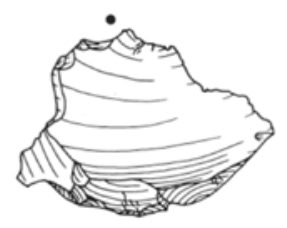

1

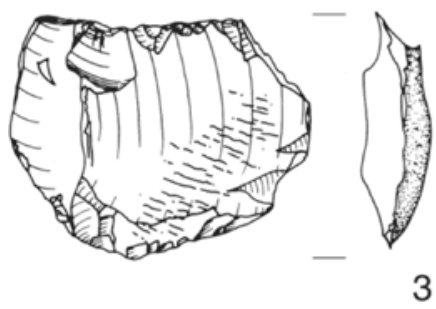

3

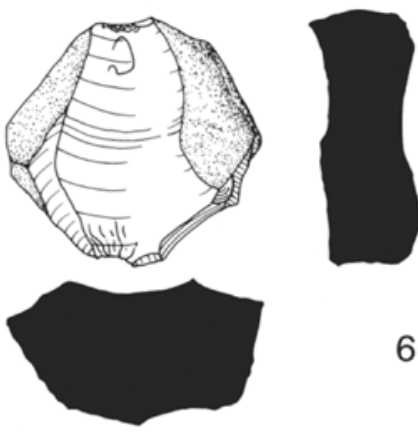

6

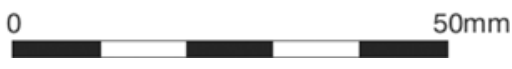

Fig. 5.

Chipped stone artefacts: 1. TP 1, 007 flake; 2. TP 2, 007 sample 24, bipolar chunk; 3 . TP 1, 007, bipolar/anvil supported core; 4 . TP 2, 007 tertiary flake; 5. TP 2, 011 sample 21 , small flake found with cod bones; 6 . TP 12, 005, bipolar core; 7. TP 6, 005 bipolar flake

\section{SPECIALIST STUDIES: FINDS \& MARINE RESOURCES}

\section{Sample processing}

Apart from four samples dry sieved on site using a $3.2 \mathrm{~mm}$ sieve, all bulk samples were sorted under laboratory conditions. Terrestrial mollusc shells were recovered but are not reported here (Cerón-Carrasco nd). Following specialist evaluation, these were gently washed, air dried, and sieved using $2 \mathrm{~mm}, 1 \mathrm{~mm}$ and $0.5 \mathrm{~mm}$ mesh. All artefactual pieces, shell, and bone were manually extracted from the $1 \mathrm{~mm}$ and $2 \mathrm{~mm}$ fractions and charred macroplant remains from the $2 \mathrm{~mm}$ residue.

\section{Lithic assemblage}

(Nyree Finlay)

The surface assemblage collected by Jardine comprises 17 flakes ( 4 primary, 9 secondary, and 4 tertiary: flake length range 13-48 mm), an irregular blade, two chunks, and a bipolar core (Finlay \& Jardine 2015, 42; all classifications after Finlayson et al. 2000). The excavated chipped stone finds comprise 48 pieces: 20 flint, 23 quartz, 4 quartzite, and 1 siltstone chunk (Table 1). Most are from midden (007) in Test Pit 2 where the majority are irregular flakes; only two have regular acute edges $(>10 \mathrm{~mm})$, one flint and bipolar, the other quartzite. Overall, there are no signs of deliberate secondary modification; a flint chunk and flake have areas of serrated edge damage. Test Pit 1 also produced evidence of bipolar working is in the form of a bipolar flake core (Fig. 5.3) and worked quartz chunks, one clearly bipolar. The only find from the lower midden layer (011, SF 21) is a single small tertiary flake associated with Gadidae bone (Fig. 5.5). The assemblage from the other test pits is limited but also characterised by bipolar reduction (eg, Fig. 5.6, core from Test pit 12 \& Fig. 5.7, Test Pit 6 bipolar flake). Of note is a burnt worked siltstone chunk (Test Pit 14) and a quartzite splintered flake and edge-damaged chunk (Test Pit 13).

There is no indication of blade platform reduction in the assemblage as commonly seen in microlith-rich sites from Colonsay and neighbouring islands (Mithen \& Finlay 2000; Mithen 2000b; Pirie et al. 2006; Wicks et al. 2014). Bipolar reduction signatures predominate in the flint assemblage and are commensurate with the chronological age of the deposits. Two flakes have crushed platforms and most show signs of bipolar or anvil-supported working. Complete flint flake lengths range from $14 \mathrm{~mm}$ to $24 \mathrm{~mm}(\mathrm{n}=5)$ and the two quartzite flakes are 24-25 mm long. Although mostly patinated and burnt, two partially patinated flakes indicate the use of original grey and brown flint beach pebble resources. One of the bipolar cores with a previous flake platform has been re-orientated and worked at $90^{\circ}$ (Fig. 5.5, Test Pit 1, 007, SF13, length $28 \mathrm{~mm}$ ), the other has one main removal from a sub-angular pebble (Fig. 5.6: Test Pit 12, SF2.2, length $26 \mathrm{~mm}$ ).

The chipped stone artefacts are similar in both technology and condition to those found at the Oronsay midden sites namely, heavily corticated beach-pebble flint flakes and cores fashioned using direct platform percussion and bipolar strategies (Finlay 1997; 
N. Finlay et al. REVISING SETTLEMENT MODELS, MESOLITHIC-NEOLITHIC TRANSITION, W. SCOTLAND

TABLE 1: LITHIC ASSEMBLAGE COMPOSITION

\begin{tabular}{|c|c|c|c|c|c|c|c|c|c|c|}
\hline Test Pit & 1 & 1 & 1 & 2 & 2 & 2 & 6 & 12 & 13 & 14 \\
\hline Context & unstratified & 007 & 011 & $u / s$ & 003 & 007 & - & - & - & - \\
\hline \multicolumn{11}{|l|}{$\overline{\text { Flint }}$} \\
\hline core & - & 1 & - & - & - & - & - & 1 & - & - \\
\hline $\begin{array}{l}\text { chunk } \\
\text { Flakes }\end{array}$ & - & - & - & 1 & 1 & 2 & - & - & - & - \\
\hline primary & - & - & - & 1 & - & - & - & - & - & - \\
\hline secondary & - & - & - & - & - & 3 & 1 & - & - & - \\
\hline $\begin{array}{l}\text { tertiary } \\
<10 \mathrm{~mm} \text { fraction }\end{array}$ & - & - & 1 & - & - & 3 & - & - & - & - \\
\hline Flint fragment & - & - & _- & 2 & - & 1 & _- & - & _- & - \\
\hline Heat spall fragment & - & - & - & 1 & - & 1 & - & - & - & - \\
\hline Other raw materials & & & & & & & & & & \\
\hline Siltstone chunk & - & - & - & - & - & - & - & - & - & 1 \\
\hline Quartz chunk & 2 & - & - & - & 3 & 4 & - & 1 & - & - \\
\hline Quartz $<10 \mathrm{~mm}$ flakes & - & - & - & - & - & 9 & - & - & - & - \\
\hline Quartz $<10 \mathrm{~mm}$ chunks & - & 2 & - & - & - & 2 & - & - & - & - \\
\hline Quartzite chunk & - & - & - & - & - & - & - & - & 1 & - \\
\hline Quartzite flake & - & - & - & - & 1 & 1 & - & - & 1 & - \\
\hline Total & 2 & 3 & 1 & 5 & 5 & 26 & 1 & 2 & 2 & 1 \\
\hline
\end{tabular}

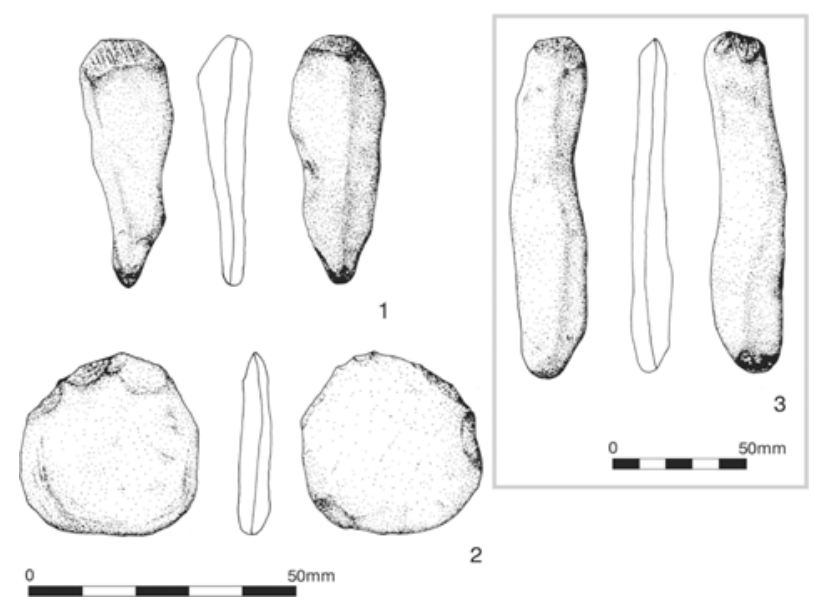

Fig. 6.

Coarse stone artefacts: 1 . TP 13, 005, SF 6, elongated pebble tool/'limpet scoop'; 2 . TP 1 , unstratified, Lithic 6 , Bifacially flaked pebble; 3. TP 2, 007, SF11, elongated pebble tool/ 'limpet hammer'

Wickham-Jones et al. 1982; Pirie et al. 2006; Wright 2007). Flint, quartz, and quartzite pebbles are found in small quantities on contemporary beaches and within raised beach deposits on both Oronsay and Colonsay (Finlay \& Jardine 2015) and resources are more ubiquitous on the flint-rich beaches of neighbouring Islay (Marshall 2000). It is likely that local beaches supplied the needs of knappers at Port
Lobh and the discard of still workable pieces in the midden suggests that concerns to conserve lithic resources were not paramount.

Quartzite and quartz pebbles are well represented in the fire-cracked rock but also appear to have been worked using direct percussion as well as bipolar strategies. Vein quartz is readily available locally but appears not to have been utilised for tool production. There are several struck quartz chunks, a few quartzite flakes, and a regular-edged chunk with some edge damage and small fraction $(<5 \mathrm{~mm})$ quartz debitage. The sizes of quartz pieces are comparable to flint; more obtuse edges predominate in the coarser grained materials.

Coarse Stone: Three coarse stone pebble tools were found during excavation and a possible fourth collected by Jardine in the eroding downslope of the main midden mound in 1990 (Finlay \& Jardine 2015, 42). Elongated pebble tools (EPTs) are a common feature at sites in the region where wear traces are often minimal or difficult to interpret as genuine use modification (Clarke 1990; 2009; Mithen \& Finlay 2000, 402). Two of the excavated pieces are classic examples of elongated pebble tools. One would traditionally be termed a limpet scoop'. This piece has a bevelled and ground edge $\left(50^{\circ}\right)$ at the widest end which tapers to a rounded and slightly ground point at the other end. This piece also has a slight area of pitted damage on one side (Fig. 6.1, Test Pit 10, SF6, L 48 mm; W 18mm; 
Th $10 \mathrm{~mm}$, Wt $12.7 \mathrm{~g})$. Another is a larger EPT, a 'limpet hammer', recovered from near the base of the main midden deposit sondage (Fig 6.3, Test Pit 2, SF11, L: $132 \mathrm{~mm}$; W: $28 \mathrm{~mm}$, Th: $17 \mathrm{~mm}$; Wt: $98.3 \mathrm{~g})$. This pebble has a pronounced sinuous shape on one side and fits comfortably in the hand, it is weighted towards one end that has a slightly ground edge. The other end is flaked bifacially with a ground bevelled edge, the flake scars extend back $c .10 \mathrm{~mm}$ and predate grinding at this thinner (12 mm wide) end. The third piece is more ambiguous, a possible small flaked tool; a thin subrounded schist pebble with a flattened abrupt smooth edge, the opposite thinner edge has unifacial flaking and some limited bifacial removals (Fig. 6.2, Test Pit 1: L: $34 \mathrm{~mm}$; W: $33 \mathrm{~mm}$; Th: $7 \mathrm{~mm}$; Wt: $13.3 \mathrm{~g}$ ).

Detailed information on the coarse stone tools from the Oronsay excavations is not widely available but single-ended elongated pebble tools were the most common type at Cnoc Coig (Nolan 1986, Table 10). Experimental work has long contributed to the interpretation of these stone implements which have been demonstrated to be highly effective in removing limpets from rocks (Lacaille 1951; Birch 2009) but could have been put to multiple functional uses including hide working and other tasks (Clarke 2009).

Pumice: Of the two unworked pieces of brown pumice found (context 003, Test Pit 2), one is rounded (Diam.: $36 \mathrm{~mm}$; Wt: $8 \mathrm{~g}$ ), the other, lighter in colour, is smaller and flatter (L: $14 \mathrm{~mm}$; Wt: $0.3 \mathrm{~g}$ ). Unworked and grooved pumice was also found at Staosnaig (Mithen \& Finlay 2000), Cnoc Coig (Nolan 1986) and Cnoc Sligeach (Bishop 1914, 99).

Fire-cracked rock (Dene Wright): Over 80 individual pieces of fire-cracked rock were identified scattered throughout the midden. Detailed analysis of over 40 larger pieces (ranging in size 30-90 mm max. dimension, Test Pit 2, 007) suggests that most derive from quartzite sub-oval pebbles, similar-sized white quartz beach pebbles, and to a lesser extent flattened sandstone cobbles (Wright 2007).

\section{Antler, mammal, \& bird bone \\ (Catherine Smith)}

Identified bone comprises the calcined distal end of the left humerus of an adult otter (Lutra lutra) (Test Pit 12, 005), a single otter adult left upper molar and a further ten calcined unidentifiable mammal bone fragments (Test Pit 2, 007, Sample 12). A single abraded red deer (Cervus elaphus) antler beam fragment broken at either end was also recovered (Test Pit 12, 005). There are two bird bones (Test Pit 1, 011), one an undiagnostic rib fragment and a carpometacarpus from a small wader (identifiable to the order Charadriformes). There are also a house mouse mandible (Mus musculus domesticus) and two unidentifiable mammal bone fragments from this context (Smith 2009).

The condition of the bird and mammal bone fragments (with the exception of the mouse bone) suggests these are of antiquity and represent food refuse. Although only one otter bone and a single tooth were recovered from two separate contexts at Port Lobh, it is equally likely that these represent consumption and discard activities involving the roasting of the carcass or subsequent bone disposal on an open fire. Otter remains were also recovered from Oronsay (Bishop 1914, 105); the majority of animals from the 1970s' excavations were adult and about half the bones were burnt; loose teeth were also common finds (Grigson \& Mellars 1987).

\section{Charcoal and charred macroplant remains}

(Susan Ramsay)

All six samples from the main shell midden (007) contained Hazel (Corylus avellana) nut shell fragments and similar charcoal assemblages, usually with Salix (willow) and cf Quercus (probable oak) present, although Alnus (alder) and Corylus (hazel) were also noted (Table 2). These species are characteristic of local woodland resources and show no sign of driftwood. The tentative identification of cf Quercus is due to the small fragments. The charcoal sample from the lower midden layer (011) had only small amounts of Maloideae (rowan type). This type includes rowan, crab apple, and hawthorn as well as less common trees and shrubs.

\section{Fish}

(Ruby Cerón-Carrasco)

Almost 3000 fish bones were recovered, of which $45 \%$ are unidentifiable fragments. Fish remains were identified, where possible, to species level or to family group, using a modern fish bone reference collection (nomenclature follows Wheeler \& Jones 1989, 122-3). All elements were examined for signs of butchery and burning. Sizes of the cod family species 
N. Finlay et al. REVISING SETTLEMENT MODELS, MESOLITHIC-NEOLITHIC TRANSITION, W. SCOTLAND

TABLE 2: CHARCOAL AND MACROPLANT REMAINS

\begin{tabular}{lccccccc}
\hline Test Pit & 1 & 1 & 1 & 2 & 2 & 2 & 2 \\
Context & 007 & 007 & 011 & 007 & 007 & 007 & 007 \\
Sample & 15 & $20^{*}$ & 27 & 12 & 13 & 16 & 24 \\
\hline Charcoal & $1(0.01 \mathrm{~g})$ & - & - & $4(0.05 \mathrm{~g})$ & - & - & - \\
Alnus (alder) & - & - & - & $1(0.01 \mathrm{~g})$ & - & - & - \\
Corylus (hazel) & - & - & $3(0.03 \mathrm{~g})$ & - & - & - & - \\
Maloideae (rowan type) & $1(0.01 \mathrm{~g})$ & - & - & $3(0.10 \mathrm{~g})$ & $3(0.05 \mathrm{~g})$ & $3(0.07 \mathrm{~g})$ & $7(0.14 \mathrm{~g})$ \\
cf Quercus (cf oak) & $3(0.04 \mathrm{~g})$ & - & - & - & $2(0.03 \mathrm{~g})$ & $1(0.01 \mathrm{~g})$ & $2(0.03 \mathrm{~g})$ \\
Salix (willow) & - & $2(0.02 \mathrm{~g})$ & - & $1(0.02 \mathrm{~g})$ & - & $1(0.01 \mathrm{~g})$ & - \\
Indeterminate bark & $1(0.03 \mathrm{~g})$ & - & - & - & - & - & - \\
Indeterminate twig & & - & - & $9(0.14 \mathrm{~g})$ & $5(0.07 \mathrm{~g})$ & $6(0.03 \mathrm{~g})$ & $15(0.18 \mathrm{~g})$ \\
Other & & - & - & & &
\end{tabular}

(fragment counts and weights: all $2 \mathrm{~mm}$ samples, except *dry sieve onsite $3.2 \mathrm{~mm}$ mesh, no identified remains in $>1 \mathrm{~mm}$ residue)

TABLE 3: FISH SPECIES REPRESENTATION AND NISP (NUMBER OF IDENTIFIABLE SPECIMENS PRESENT)

\begin{tabular}{lccccccc}
\hline Test Pit & 1 & 1 & 2 & 2 & 3 & 10 & NISP \\
Context & 007 & $011 / 012$ & 003 & 007 & 004 & 005 & - \\
Species & & & & & & & \\
\hline Saithe & 139 & 15 & 4 & 1358 & 2 & 5 & 1523 \\
Cod & 2 & 44 & 1 & 25 & - & - & 72 \\
Norway Pout & - & - & - & 1 & - & - & 1 \\
Gadidae & - & - & - & 1 & - & - & 1 \\
Total & 141 & 59 & 5 & 1385 & 2 & 5 & 1597 \\
\hline
\end{tabular}

(Gadidae) were given an approximate size range by matching the archaeological material to modern fish skeletons of known size based on 'total body length'. Therefore, elements were categorised as very small $(<15 \mathrm{~cm})$, small $(15-30 \mathrm{~cm})$, medium $(30-60 \mathrm{~cm})$, and large $(60-120 \mathrm{~cm})$. Four marine taxa were identified: three to species and one to family level. Saithe (Pollachius virens) is the main species represented, the others being cod (Gadus morhua), Norway-pout (Trisopterus esmarkii), and other species of the family Gadidae (Tables 3 and 4).

The level of preservation of the fish bone was consistent, in terms of both fragment size and condition. Bones were most frequently 40-70\% complete (55\%, with fewer than $1 \%$ being $81+\%$ complete). Fish bone preservation state is measured on texture (on a scale of 1-5, fresh-extremely crumbly) and erosion (on a scale of $1-5$, none-extreme). The sum of both was used as an indication of bone condition; fresh bone would score 2 while extremely poorly preserved bone would score 10 (after
Nicholson 1991). The condition score was generally in the range of 7-8 indicating poor to extremely poorly preserved bone. Some of the fish remains were burnt white, indicative of burning at a high temperature (Table 5).

Saithe, the dominant species present, inhabit shallow coastal waters, particularly in their first 3-4 years. According to modern fisheries data, they range $15-55 \mathrm{~cm}$ in total length during this age range. Saithe has been one of the most important fish food species recorded for the early prehistory of Scotland (Barrett et al. 1999) and was an important source of nourishment to large numbers of the population until the 19th century AD in the Scottish islands (Cerón-Carrasco 2005). The large amount of fish remains at Port Lobh represents mostly $15-30 \mathrm{~cm}$ long individuals, ie, specimens in their 1st-3rd year. Quantities of fish in this size range would have significantly contributed to human diet, being an easily accessible resource that are easily caught using simple technology around low tide (Barrett et al. 1999). Norway-pout is represented 
THE PREHISTORIC SOCIETY

TABLE 4: FISH SPECIES AND IDENTIFIED ELEMENT TYPE

\begin{tabular}{lccccc}
\hline $\begin{array}{l}\text { Species } \\
\text { Element }\end{array}$ & $n$ & Saithe & Cod & Norway Pout & Gadidae \\
\hline articular/l & 1 & 1 & - & - & - \\
ceratohyal & 2 & 2 & - & - & - \\
clavicle & 1 & 1 & - & - & - \\
Caudal vertebra & 872 & 808 & 64 & - & - \\
epihyal & 1 & - & - & - & 1 \\
maxilla/l & 4 & 4 & - & - & - \\
maxilla/r & 1 & 1 & - & - & - \\
otolith & 135 & 133 & 1 & 1 & - \\
parasphenoid & 1 & - & - & - & - \\
precaudal vertebra & 608 & 596 & 12 & - & - \\
pharyngeal & 1 & 1 & - & - & - \\
premaxilla/l & 3 & 3 & - & - & 2 \\
quadrate/l & 1 & 1 & - & - & 1 \\
Total & 1631 & 1551 & 77 & - & \\
\hline
\end{tabular}

( 1 = left, $r=$ right $)$

TABLE 5: BURNT IDENTIFIED SAITHE BONES

\begin{tabular}{lc|cccccc}
\hline Test Pit & 1 & & & & \\
\hline Context 007 sample & 15 & 12 & 13 & 16 & 18 & 24 & 25 \\
caudal vertebra (vs) & 9 & 16 & 15 & 21 & 2 & 6 & 13 \\
precaudal vertebra (vs) & - & 14 & 15 & 17 & - & 4 & 9 \\
precaudal vertebra (s) & - & - & - & - & - & - & 32 \\
Total & 9 & 30 & 30 & 38 & 2 & 10 & 22 \\
\hline
\end{tabular}

(vs = very small; s = small)

by one otolith (Test Pit 2) and was probably caught whilst catching saithe.

In the Scottish Islands in the recent past such fish were caught by frame-nets $(t a b h)$ or simple rod and line from the shore and from boats in shallow water. Pounded limpet meat was traditionally used to attract young saithe (Cerón-Carrasco 2005). If the growth rates of saithe have been consistent through time then fishing for saithe at Port Lobh could have occurred throughout the year rather than in a single short season. The predominance of small and very small fish suggests they were caught between July and November. The medium and large cod could indicate a more complex technology and the use of a boat further offshore (Table 6). In inshore waters they can be caught from shore using line and hook or by harpoon. In sum, the main species exploited belonged to the Gadidae family with a predominance of immature saithe. The rocky shoreline immediately near the site would have allowed for an extensive exploitation of immature saithe whilst offshore fishing with hand lines would guarantee supply of other larger gadids such as mature cod.

Saithe otolith seasonal zones: a pilot study

(Peter J Wright \& Julian Augley)

The ability to estimate the season of capture using otolith seasonal zones has been demonstrated from comparisons of historic and modern-day otoliths (Van Neer et al. 1999). A pilot study to estimate the season of capture of saithe using otolith seasonal zones was undertaken on seven otoliths using $0.5 \mathrm{~mm}$ transverse sections illuminated with reflected light. Typically, two seasonal zones of different opacity are formed in otoliths each year (Wright et al. 2002a). An opaque zone usually forms when fish are growing rapidly whilst a translucent zone with narrow daily increments is formed when growth is minimal (Wright et al. 2002b). In modern Scottish coastal waters, the translucent zone is mainly formed during the period of lowest 
N. Finlay et al. REVISING SETTLEMENT MODELS, MESOLITHIC-NEOLITHIC TRANSITION, W. SCOTLAND

TABLE 6: PROFILE OF COD BONES (ALL UNBURNT)

\begin{tabular}{lccccc}
\hline & \multicolumn{2}{c}{ Test Pit 1 } & \multicolumn{3}{c}{ Test Pit 2 } \\
Context & 007 & 011 & 011 & 003 & 007 \\
Sample & 20 & 21 & 27 & sieve & 24 \\
\hline Caudal vertebra & 1 & - & - & & - \\
large & 1 & 35 & 3 & - & - \\
medium & - & - & - & - & 24 \\
small & - & - & - & - & 1 \\
Otolith (small) & - & 4 & 2 & 1 & - \\
Precaudal vertebra & - & - & - & - & 5 \\
medium & 2 & 39 & 5 & 1 & 30 \\
small & Total & & &
\end{tabular}

TABLE 7: MARINE SHELL SPECIES NISP COMPOSITION

\begin{tabular}{llccccccc}
\hline & \multicolumn{1}{c}{ Test Pit 1 } & \multicolumn{2}{c}{ Test Pit 2 } & Test Pit 3 & Test Pit 10 & NISP \\
& $\begin{array}{c}\text { Context } \\
\text { Common name }\end{array}$ & 007 & $011 / 012$ & 003 & 007 & 004 & 005 & - \\
Species & & & & & & & & \\
\hline Patella vulgata & Limpet & $214+$ & $3+$ & $264+$ & $1776+\mathrm{b}$ & + & 95 & 2352 \\
Littorina littorea & Periwinkle & 100 & + & $98+\mathrm{b}$ & $1072+$ & 6 & 47 & 1323 \\
Nucella lapillus & Dog-whelk & + & - & + & $4+$ & - & + & 4 \\
Mytilus edulis & Mussel & + & - & - & + & - & - & - \\
Ostrea edule & Oyster & - & 1 & 1 & 2 & 1 & 5 & 4 \\
Littorina obtusata littoralis & Top shell & - & - & - & 4 & - & - & 2 \\
Ensis ensis & Flat periwinkle & - & - & - & 2 & - & - & 2 \\
Lutraria lutraria & Razor shell & - & - & - & 1 & - & 1 & 1 \\
Rissoa parva & Otter shell & 1 & - & - & - & - & - & 1 \\
Chlamys opercularis & Rissoa parva & - & - & - & 1 & - & - & - \\
Buccinum undatum & Queen scallop & - & - & - & + & - & - & - \\
\hline
\end{tabular}

(+ fragments present, b burnt fragments present)

fish growth and declining sea temperatures, between October and March. Saithe otoliths were examined from three midden (007) (007) samples: two Test Pit 2 otoliths (Fig. 7, 12.1-3 \& specimen 25, not illustrated) and three from Test Pit 1 (context 007, Fig. 7, 15.1-3). While specimen 25.2 did not have clear zones it appears to be too large to be a young of the year (0-group). All other samples may have been 0 -group as the first translucent zones in 12.2, 15.1, and 15.2 and were similar in appearance to false rings (ie, a narrow and often incomplete translucent zone within an opaque zone that is not formed in winter; Wright et al. 2002a). The translucent edge in all otoliths suggests that the samples came from the autumn-winter period. Saithe 25.1 had probably settled shortly before capture because the otolith was small, and the translucent edge had just started to form, consistent with that seen in recently settled young of the year. This type of otolith can be found as early as August. Most other samples had a larger translucent edge, suggesting a probable capture period of October-December. However, the wide translucent zone in 15.3 may mean this fish was captured later but before spring.

\section{Marine Mollusca}

(Ruby Cerón-Carrasco)

The majority of the marine shell was hand recovered from the laboratory processing of bulk samples (to 1 $\mathrm{mm}$ fraction size) and from a single on-site dry sieved (3.2 mm mesh) sample (Tables $7 \& 8$ 8). Apical fragments were identified to species using standard 

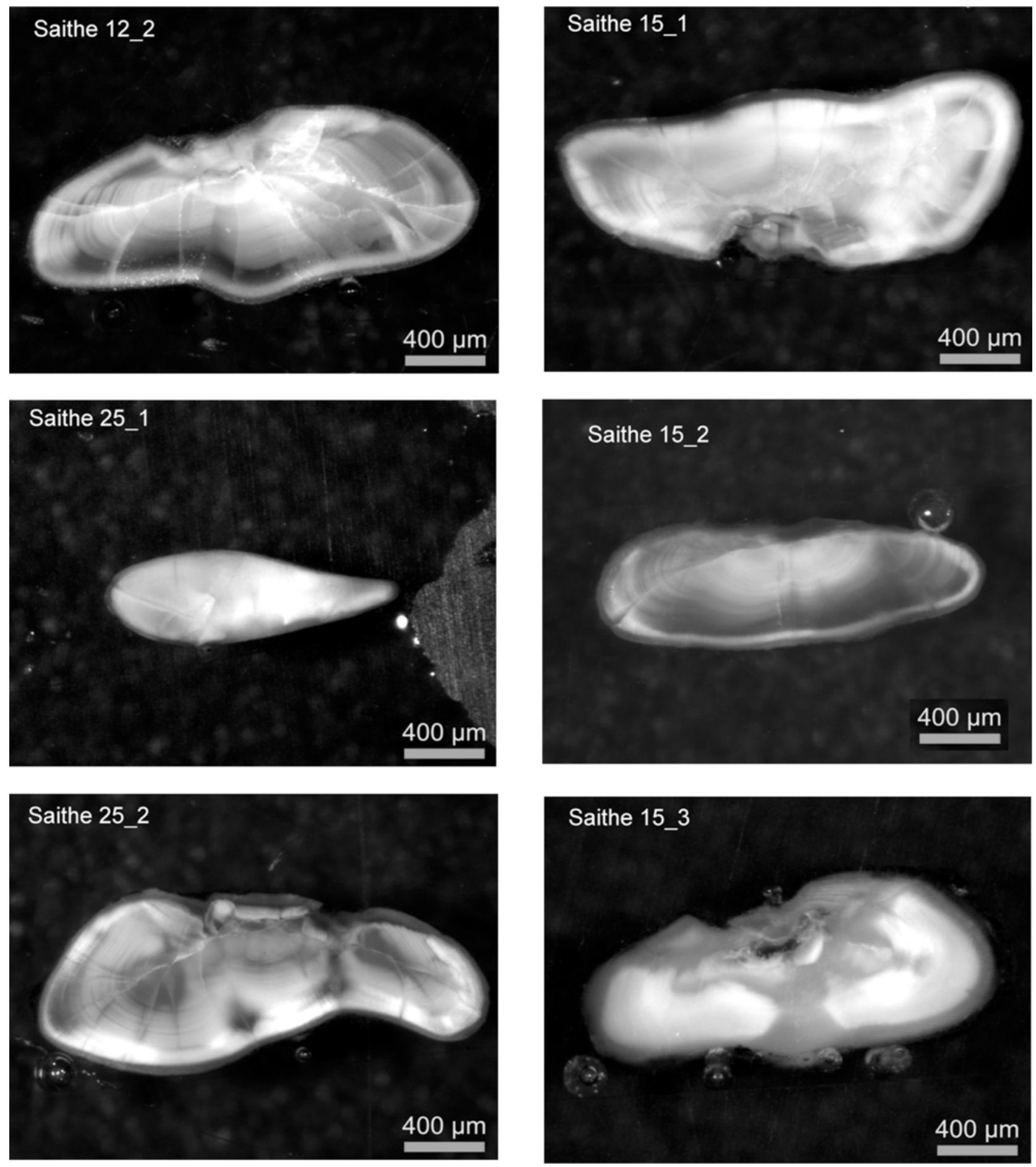

Fig. 7.

Saithe otolith sample thin-sections 
N. Finlay et al. REVISING SETTLEMENT MODELS, MESOLITHIC-NEOLITHIC TRANSITION, W. SCOTLAND

TABLE 8: LIMPET AND PERIWINKLE COMPOSITION BY TYPE AND SAMPLE

\begin{tabular}{lcccccccc}
\hline Test Pit & Context & Sample & $\begin{array}{c}\text { Limpet }(S) \\
\text { mature }\end{array}$ & $\begin{array}{c}\text { Limpet }(S) \\
\text { juvenile }\end{array}$ & $\begin{array}{c}\text { Limpet }(R) \\
\text { mature }\end{array}$ & $\begin{array}{c}\text { Limpet }(R) \\
\text { juvenile }\end{array}$ & $\begin{array}{c}\text { Periwinkle } \\
\text { mature }\end{array}$ & $\begin{array}{c}\text { Periwinkle } \\
\text { Juvenile }\end{array}$ \\
\hline 1 & 007 & 15 & 31 & 100 & 4 & 30 & 76 & 10 \\
2 & 007 & 12 & 510 & 64 & 7 & 24 & 59 & 61 \\
2 & 007 & 13 & 25 & 180 & - & 17 & 87 & 45 \\
2 & 007 & 16 & 64 & 78 & - & - & - & - \\
2 & 007 & 18 & 53 & 346 & & 20 & 62 & 74 \\
2 & 007 & 24 & 74 & 614 & 11 & 12 & - & 16 \\
2 & 007 & 25 & 6 & 64 & 2 & 18 & 16 & 16 \\
\hline
\end{tabular}

( $\mathrm{S}$ - smooth; R - ribbed; limpet juvenile size $<30 \mathrm{~mm}$; periwinkle juvenile $<20 \mathrm{~mm}$, after Baxter (1982); sample $183.2 \mathrm{~mm}$ mesh size)

guides (Campbell \& Nicholls 1989; Moreno-Nuño 1994a). Frequency was estimated by counting shell apices for gastropods and valve umbos for bivalve species (Moreno-Nuño 1994b).

The marine shell assemblage is summarised in Table 7. The majority of species recovered from archaeological sites throughout the Scottish islands still occur in the fauna of the locality, thereby facilitating identification and the consideration of habitat. No modern environmental sampling from the site locality was conducted and the interpretations below draw on wider local and regional comparative studies (eg, Russell et al. 1995; Milner 2009a). In attempting to reconstruct aquatic habitat from the analysis of shell recovered in archaeological deposits, shell size and shape are a significant indicator of water temperature and current speed. For such purposes, only specimens that had reached sexual maturity would have achieved the characteristic shell growth complementary with the environment they inhabit (Kitching et al. 1966; Tavesz \& Carter 1980).

Limpets: The main species represented is the limpet (Patella vulgata), a species of major importance on most littoral shores and in shallow waters (Branch 1985). It is present on all rocky shores from the most sheltered ones dominated by the algae Ascophyllum nosodum (L.) to the most exposed, mussel and barnacle dominated types.

Studies of archaeologically retrieved marine shell, dating to the Mesolithic, have used morphological characteristics of gastropod species such as the dogwhelk (Nucella lapillus) to investigate possible environmental changes since the period in which these were collected and deposited at the sites (Andrews et al. 1987; Russell et al. 1995; Milner 2009a). The limpet is also used for the same purpose and here only mature specimens are used for the overall environmental analysis. Growth rates of limpets vary considerably although studies in Orkney have shown that rates of growth are consistent from year to year (Baxter 1982). Characteristically limpet growth rates are fastest in the first year, ranging from $5-15 \mathrm{~mm}$, declining by their third year to $3-10 \mathrm{~mm}$ growth. The growth rate then tends to remain relatively constant for several years before virtual cessation. Differences of limpet shell associated micro-habitat type of beach and level suggest that the study of shell allometry can offer a means of detecting and describing changes in the environment (Jones \& Baxter 1985). Limpets on the lower shore are more exposed to the forces of waves than those on the upper shore, therefore the shells are more conical at the upper shores and flatter at the lower. A flatter shell has a smaller wave impact area than a more conical shell and is less likely to be knocked off the substrate if it has a more streamlined shape.

Measurements on a sample of limpets $(\mathrm{n}=16$, Context 007) produced aperture lengths of $1.12-2.26 \mathrm{~mm}$ $(1.54 \pm 0.35 \mathrm{~mm})$ and widths of $3.22-4.82 \mathrm{~mm}$ (average $3.9 \pm 0.49 \mathrm{~mm}$ ) producing a Relative Aperture Size (RAS, aperture width/shell length) calculation of $2.68 \pm 0.49 \mathrm{~mm}$ (measurements after Baxter 1982). This suggests that limpets were gathered from exposed areas, as their flattened shape would have protected them from strong wave action (Baxter 1982; Campbell 2008). Since most of the specimens from the site were similarly flattened it is assumed that these were more exposed to stormy conditions. An in-depth study of the limpet assemblage was subsequently undertaken by Winton (2018). This analysis included measurements of height and length ratio of multiple specimens which show that limpet were 


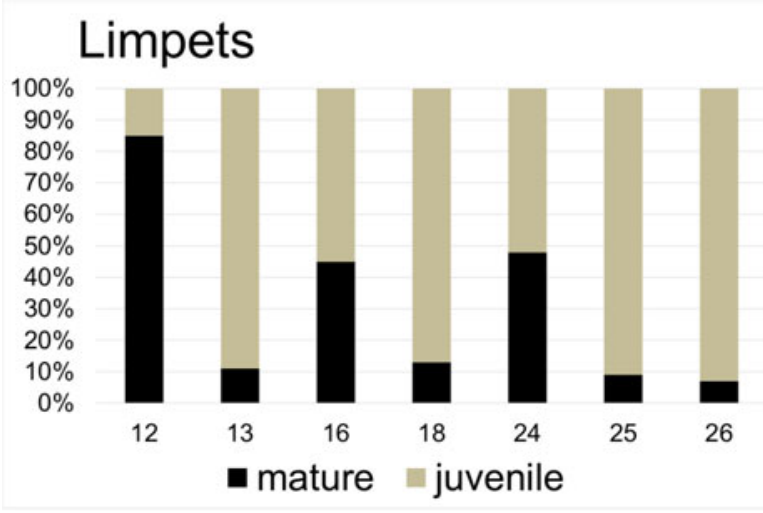

\section{Periwinkles}

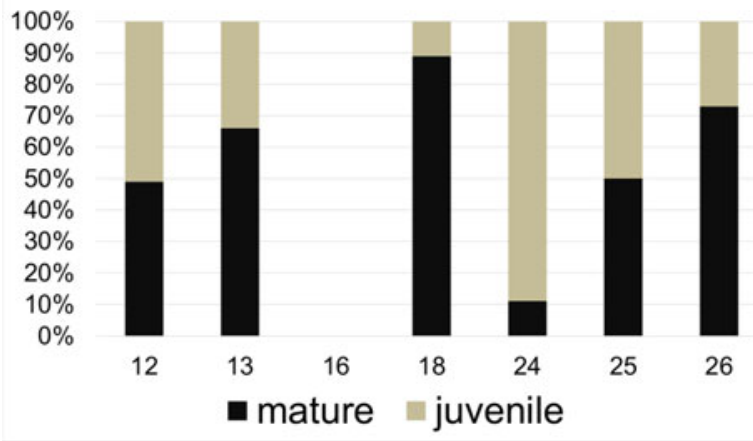

Fig. 8.

Limpet and periwinkle sample composition by inferred age and percentage of NISP (Number of Identifiable Specimens

Present)

likely to have been collected from both low and high shores (Fig. 8; see Table 12).

The large concentration of limpets and their characteristic shell shape are consistent with an exposed shoreline, like that close to the site, but may simply be indicative of the environment that the species collected inhabited. Violent wave action and high storm frequency may also explain the limpet shell shape and further analytical work is being undertaken on the assemblage.

Mellars (1978) discusses how the occupants of Colonsay in relatively recent times collected limpets from low tide locations since they were considered to be tender and more palatable than those collected from higher parts of the shore. There is a greater proportion of immature limpets in the Port Lobh assemblage which makes evaluation of the shore collection zone problematic (Fig. 8; Table 8). This could imply that these were largely used as fishing bait rather than gathered directly for human consumption; the large amounts of immature saithe bones would also support this notion.

Periwinkles: The edible periwinkle (Littorina littorea) was also plentiful. Mature periwinkles are slightly more abundant in the Port Lobh assemblage, although the number of immature specimens is also significant in certain samples (Fig. 8). It is therefore concluded that periwinkles were gathered primarily as a foodstuff. Studies indicate that there is no significant allometric differences in Littorina littorea shell of individuals from different environments (Hylleberg \& Christensen 1977).

Other species: Both limpets and periwinkle inhabit rocky locations which would also explain the presence of the dog whelk Nucella lapillus, though in very small amounts which may have been caught accidentally whilst gathering periwinkles. The flat periwinkle and Rissoa parva specimens may have been gathered along with the seaweed which these species are associated. Limpets, periwinkles, whelk, and dog whelk are gastropods that have very sturdy shells which survive well in archaeological deposits. Species from sandy substrates are also present, mainly bivalves, and include oyster, razor shell, otter shell, and mussel which have quite fragile shells that break easily with less chance of survival. One gastropod that was present in the assemblage that is found in muddy/sandy substrates is the whelk (Buccinum undatum) although only in one sample compared to the rocky shore dwellers.

\section{Crustacean and echinoidea remains}

(Ruby Cerón-Carrasco)

Crustacean remains were classed as either claw or carapace. Most are likely to be edible crab (Cancer pagurus) and all fragments were burnt, implying food residue. Fragments were quantified to relative frequency (Table 9). One sample from Test Pit 2, Context 007) also contained unburnt remains of the edible sea urchin Echinus esculentus which is abundant in the west coast of Scotland (Boyd \& Boyd 1996a; 1996b). Sea urchin was found at the Bronze Age site of Northton, Harris (Renfrew 1993, 18) and in the Late Iron Age settlement at Cnip, Lewis (Cerón-Carrasco 2006) but none, to our knowledge, is reported from earlier Scottish 
N. Finlay et al. REVISING SETTLEMENT MODELS, MESOLITHIC-NEOLITHIC TRANSITION, W. SCOTLAND

TABLE 9: CRUSTACEAN REMAINS

\begin{tabular}{lccll}
\hline Test Pit & Context & Sample & Carapace & Claw \\
\hline 1 & 007 & 15 & $* *$ & $* *$ \\
& 007 & 20 & $* *$ & - \\
2 & 011 & 22 & $* * *$ & $* * *$ \\
& 003 & 1 & $* * * *$ & - \\
& 007 & 12 & $* * * *$ & $* * *$ \\
& 007 & 13 & $* * *$ & $* * * * *$ \\
& 007 & 16 & $* * * *$ & $*$ \\
& 007 & 24 & $* * *$ & $*$ \\
10 & 007 & 25 & $*$ & $* *$ \\
\hline
\end{tabular}

All burnt fragments, all probably Cancer pagurus. Key: ** present, minimal amount, $* *$ moderate amounts present, $* * *$ common, indicating relatively large amounts

midden sites. Sea urchin can be eaten raw or prepared by boiling or roasting and the spines may have been used as tools. The fact that it has not been more widely recorded archaeologically is probably due to poor retrieval practices or taphonomic losses.

\section{RADIOCARBON DATING}

\section{(Rupert Housley)}

Four radiocarbon dates were obtained on individual limpet shells from the main shell midden deposit excavations (Fig. 9; Table 10). A further AMS date of $5550 \pm 35$ BP (SUERC-16340) on Patella vulgata was returned from a midden (007) sample but has since been discounted from the modelling due to uncertainty over its test pit location. Although charred hazelnuts were available in Test Pit 2, the decision was made to use individual limpet shells to ensure consistency in dating material between test pits. The absence of charred hazelnuts in the other test pits precluded a strategy of focusing purely on short-lived terrestrial materials whose carbon derives from the atmosphere. Using a variety of material would introduce questions of comparability; at Port Lobh limpet shells were the only dating material common in all the excavation trenches.

All the measurements have been calibrated using the IntCal13 marine atmospheric calibration curve of Reimer et al. (2013) and the OxCal v4.3.2 computer program of Bronk Ramsey (2009). Radiocarbon ages of samples formed in the ocean, such as shells, are generally several hundred years older than their terrestrial counterparts. This apparent age difference is due to the large carbon reservoir of the oceans. A correction is necessary to compare marine and terrestrial samples, but because of complexities in ocean circulation the actual correction varies with location. This regional difference from the average global marine reservoir correction is designated $\Delta \mathrm{R}$ (Stuiver \& Braziunas 1993). The value of $\Delta \mathrm{R}$ used in this study to correct the age offset is $-73 \pm 52$ (Harkness 1983). The corrected age determinations are shown at $68.2 \%$ and $94.5 \%$ probability range intervals and expressed in years cal $\mathrm{BC}$ rounding out to the nearest 10 years.

Three of the samples came from within Context 007, with one further sample from the lower stratigraphic unit, Context 012. Bayesian modelling of these depositional relationships (Bronk Ramsey 2009) suggests limpet shell accumulation was taking place in the main midden (007) broadly from the latter half of the 5th to the start of the 4th millennium cal BC (Table 11). A number of possible interpretations may be drawn from the radiocarbon data. The presence of two lithological layers (012 and 007) and two pairs of statistically consistent age determinations (SUERC$16343 \&-16341$ vs. $-15043 \&-21085)$ indicate a minimum of two discrete activity episodes at the site of Port Lobh. Median ages for the two pairs of radiocarbon determinations are 4110 and $4215 \mathrm{cal} \mathrm{BC.} \mathrm{Two}$ activity events are therefore the minimum level of human visitation responsible for the archaeological record. However, the dating cannot rule out the possibility that the midden represents accumulated small individual actions extending over many generations of visits in the latter half of the 5th millennium cal BC. The radiocarbon data could support either pattern of activity as each would result in the attendant accumulation of material culture.

\section{PORT LOBH SHELL MIDDEN: INTERPRETATIONS}

The excavations reveal an extant shell midden deposit that is at least over half a metre thick with a truncated mixed sand upper deposit and an underlying unconsolidated and predominately limpet shell core. The base of the excavated main midden layer is estimated to lie at c. 13.5-13.9 m OD and is composed mainly of intact limpets and periwinkles with occasional finds of other marine species, bones, and macroplant remains and lithic material. The densest area of midden deposit from a $25 \mathrm{~cm}^{3}$ sample yielded $c .600$ complete limpets. This gives an estimated 38,720 complete limpets per cubic metre of deposits. A modern experimental collection of limpets using elongated pebble tools generated 700 


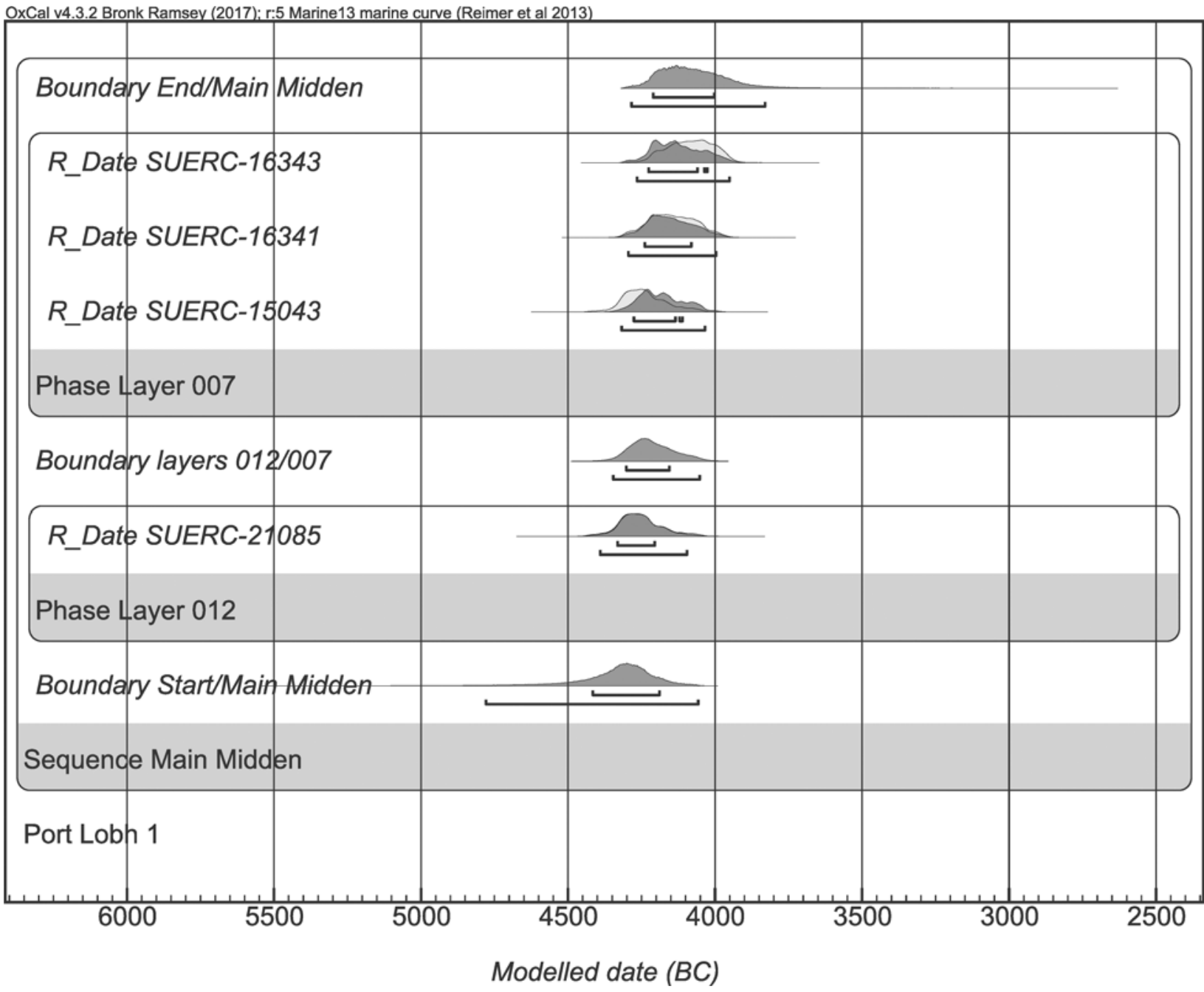

Fig. 9.

Bayesian modelling of radiocarbon determinations of limpet shells from two phases of the main midden (012 and 007). Based on OxCal v.4.3.2 (Bronk Ramsey 2009), the IntCal13 marine calibration curve (Reimer et al. 2013) and a $\Delta \mathrm{R}$ age offset of $-73 \pm 52$ (Harkness 1983)

limpets per person hour (Birch 2009) and gives some intimation of potential collection time involved.

It is probable that the brown sandy-silt layer (005) identified in several of the test pits represents denuded shell midden deposit. Marine shells, both limpets and periwinkles, were frequent inclusions in this deposit. Analysis of the sieved samples also recovered fish bone as well as some mammal bone and an antler fragment. Some typical artefacts were also recovered: flint flakes and a small pebble tool. If this deposit does indeed represent denuded shell midden then its original extent in this location may have been significant.
The more exposed western side of the midden has experienced erosion in recent memory. Rig and furrow is still visible in land to the south of the site and evidence of possible earlier spade cultivation traces at the base of Test Pit 13. In 1804 seven dwellings are reported in the neighbourhood of Port Lobh (Loder 1935, 171) and earlier structures were robbed for wall construction on the north side of the bay (Grieve 1923). Land use practices and occupation attested in the vicinity from the Iron Age onwards may have accelerated midden destruction by natural agencies. 
N. Finlay et al. REVISING SETTLEMENT MODELS, MESOLITHIC-NEOLITHIC TRANSITION, W. SCOTLAND

TABLE 10. RADIOCARBON DATES

\begin{tabular}{llccccc}
\hline $\begin{array}{l}\text { Test Pit/context/ } \\
\text { sample }\end{array}$ & Material & Lab code & $\begin{array}{c}\text { Determination } \\
B P\end{array}$ & $\begin{array}{c}\text { Date cal BC, } \\
68.2 \% \\
\text { probability }\end{array}$ & $\begin{array}{c}\text { Date cal BC, } \\
95.4 \% \\
\text { probability }\end{array}$ & $\begin{array}{c}\partial^{13} \mathrm{C} \\
(\%)\end{array}$ \\
\hline TP2/007/S12 & $\begin{array}{l}\text { Limpet shell } \\
\text { Patella vulgata }\end{array}$ & SUERC-16343 & $5555 \pm 35$ & $4160-3980$ & $4240-3940$ & 0.5 \\
TP1/007/S15 & $\begin{array}{l}\text { Limpet shell } \\
\text { Patella vulgata }\end{array}$ & SUERC-16341 & $5620 \pm 35$ & $4230-4060$ & $4300-3990$ & 1.2 \\
TP2/007/S13 & $\begin{array}{l}\text { Limpet shell } \\
\text { Patella vulgata }\end{array}$ & SUERC-15043 & $5705 \pm 35$ & $4330-4180$ & $4370-4050$ & 0.5 \\
TP1/012/SF18 & $\begin{array}{l}\text { Limpet shell } \\
\text { Patella vulgata }\end{array}$ & SUERC-21085 & $5720 \pm 40$ & $4340-4190$ & $4400-4060$ & 0.8 \\
\hline
\end{tabular}

Unmodelled calibration using Marine13 (modelled ocean average marine calibration curve of Reimer et al. 2013) with a $\Delta \mathrm{R}$ offset of $-73 \pm 52$ (Harkness 1983) and the OxCal v4.3.2 program of Bronk Ramsey (2009)

TABLE 11: BAYESIAN MODELLED AGE ESTIMATES FOR THE START AND END BOUNDARIES TO THE PORT LOBH SHELL MIDDEN

\begin{tabular}{lcc}
\hline Event/Boundary & $\begin{array}{c}\text { Modelled 68.2\% probability } \\
\text { age range (cal BC) }\end{array}$ & $\begin{array}{c}\text { Modelled 94.5\% probability } \\
\text { age range (cal BC) }\end{array}$ \\
\hline Boundary End/Main Midden & $4220-4000$ & $4290-3830$ \\
R_Date SUERC-16343 & $4230-4020$ & $4270-3950$ \\
R_Date SUERC-16341 & $4250-4080$ & $4300-3990$ \\
R_Date SUERC-15043 & $4280-4110$ & $4320-4030$ \\
Phase Layer 007 & - & - \\
Boundary 012 / 007 & $4310-4150$ & $4350-4050$ \\
R_Date SUERC-21085 & $4340-4200$ & $4390-4090$ \\
Phase Layer 012 & - & - \\
Boundary Start/Main Midden & $4420-4190$ & $4790-4050$
\end{tabular}

Age ranges rounded out to 10 years. Based on depositional modelling procedures in Bronk Ramsey (2009)

At the eastern edge the shell midden deposit thins out towards the trackway where it has been eroded and here at least two discrete depositional phases were identified in Test Pit 1. The upper midden deposit in this area appears identical in composition and character to that encountered in the main deposit in Test Pit 2. The lower layer is distinct with a more discontinuous lower shell midden layer comprising marine shell and also unburnt remains of medium and larger cod within a predominately sandy layer. No burnt hazelnut shell fragments were recovered from this deposit and only Maloideae charcoal is present. This suggests temporal as well as spatial variation in discard practices which is supported by the dating. This lower part of the midden appears to be associated with the processing of larger, unburnt fish. Similar layers were not identified in the main midden deposit where the size profile of the cod, found in one sample only, are small. The spatial separation of fish-rich layers is also a feature at the Oronsay sites (Mellars 1987). The dense shell deposit appears to be relatively uniform with some horizontal layering and potential tip lines apparent in the very limited area sampled, but with no clear stratigraphic hiatus or separation to indicate the formation of a substantial palaeosoil horizon in the Test Pit 1 deposits. However, such apparent visual uniformity masks discrete and subtle compositional variation seen in the individual arbitrary sub-samples within the small portion excavated. At the microtopographical scale the shell midden exhibits discrete compositional differences while giving an overall impression of a seemingly more uniform depositional event. This can be seen in the different potential capture season for immature saithe and in the fish size ranges when compared to modern behavioural and catch data (Hislop et al. 2015). In some 
THE PREHISTORIC SOCIETY

TABLE 12 LIMPET AND PERIWINKLE SUMMARY SHELL SIZES (MM) FROM CONTEXT 007

\begin{tabular}{lccccr}
\hline Sample & Limpet length range & Limpet average length & $n$ & Periwinkle height range & Periwinkle average height \\
\hline 12 & $21-39$ & $28.87 \pm 3.56$ & 457 & $18-37$ & $25.23 \pm 3.02$ \\
13 & $21-39$ & $28.97 \pm 3.72$ & 223 & $13-32$ & 125 \\
15 & $21-41$ & $29.15 \pm 3.88$ & 144 & $20-36$ & 118 \\
\hline
\end{tabular}

Limpet length taken from anterior to posterior and periwinkle height from apex to bottom of the aperture, measured to $0.1 \mathrm{~mm}$ using electronic calipers, after Winton (2018)

of the samples more crab or burnt fishbone are present and other differences are evident, such as the presence of lithics and fire-cracked rock. Most notable are the variation in shellfish species composition and character such as the presence of mussel or oyster. Variation can be seen in the size and shape profiles of limpets in the main midden deposit samples (Fig. 10). Differences can also be seen in the size profile of periwinkles: some of this variation is likely to relate to individual gathering and processing events (Tables $8 \& 12$ ). The flattened profile of the Port Lobh limpets suggests more exposed and lower shore conditions. Modern shellfish collection was not undertaken in this phase of the project. Previous Scottish studies on west coast Mesolithic sites have shown significant size differences between archaeological and modern control specimens (Russell et al. 1995; Milner 2009a). There are broadly equivalent general trends apparent in limpet shell morphology related to relative tidal shore collection zone but a notable overlap that reflects local conditions. Collection is often assumed to reflect the immediate vicinity of a given site but there is little current understanding of the potential geographical range of shellfish gathering, especially if boats are in use, and a range of factors may account for the observed variation.

Geophysical survey suggests that the shell midden does not survive as extensive deposits beyond the east side of the current trackway or to the south beyond the current boundary wall - although the recovery of flint bipolar artefacts suggests that comparable deposits may have been previously more extensive in these areas. While there is always the potential for further better-preserved archaeological deposits to be very deeply buried beneath wind-blown sand, our current understanding of the Port Lobh midden is now of a rather discrete, eroded, and isolated deposit, around $27 \mathrm{~m}^{2}$ in extent. The geophysical survey was very successful in defining the midden core and demonstrating that this technique is effective for shell middens in this type of coastal environment. It offers clear future potential as a routine field methodology for the noninvasive characterisation and discovery of these type of sites (Finlay \& MacAllen 2009). While the proximity of the main midden to the surface clearly enhanced geophysical responses, the discovery of a separate buried Iron Age marine shell-rich deposit demonstrates the value of this method for the detection of similar unknown features (Finlay et al. 2019).

\section{DISCUSSION}

\section{Calling time on Oronsay settlement and subsistence models?}

Port Lobh is the first shell midden discovered on Colonsay comparable in age and character to sites on Oronsay. That it was revealed over a number of years through the regular recovery of lithic artefacts is a salutary lesson in the value of landscape familiarity and systematic low-key lithic collection (Finlay \& Jardine 2015).

The significance of the fieldwork, however, lies in the identification of a new shell midden on Colonsay and evidence regarding food consumption practices and lifestyle in the 5th-4th millennia cal BC. Port Lobh directly contributes to the ongoing debate regarding subsistence practices and sedentism on Oronsay during this period and understandings of lifeways around the Mesolithic-Neolithic transition. Excavation and radiocarbon dating reveal that this shell midden is contemporaneous with deposits in the Oronsay midden sites. It presents a similar character and profile in terms of a focus on saithe and shellfish collection in which limpet and periwinkle constitute the dominant species.

In this discussion section, three separate themes are explored. The first examines subsistence practices at Port Lobh and reflects on the wider importance of the saithe otolith thin-section data to consider temporal rhythms and seasonality signatures. The second addresses the need to re-evaluate the significance of the Oronsay sites, identifying critical issues around their archaeological visibility and survival. Finally, the third 
N. Finlay et al. REVISING SETTLEMENT MODELS, MESOLITHIC-NEOLITHIC TRANSITION, W. SCOTLAND
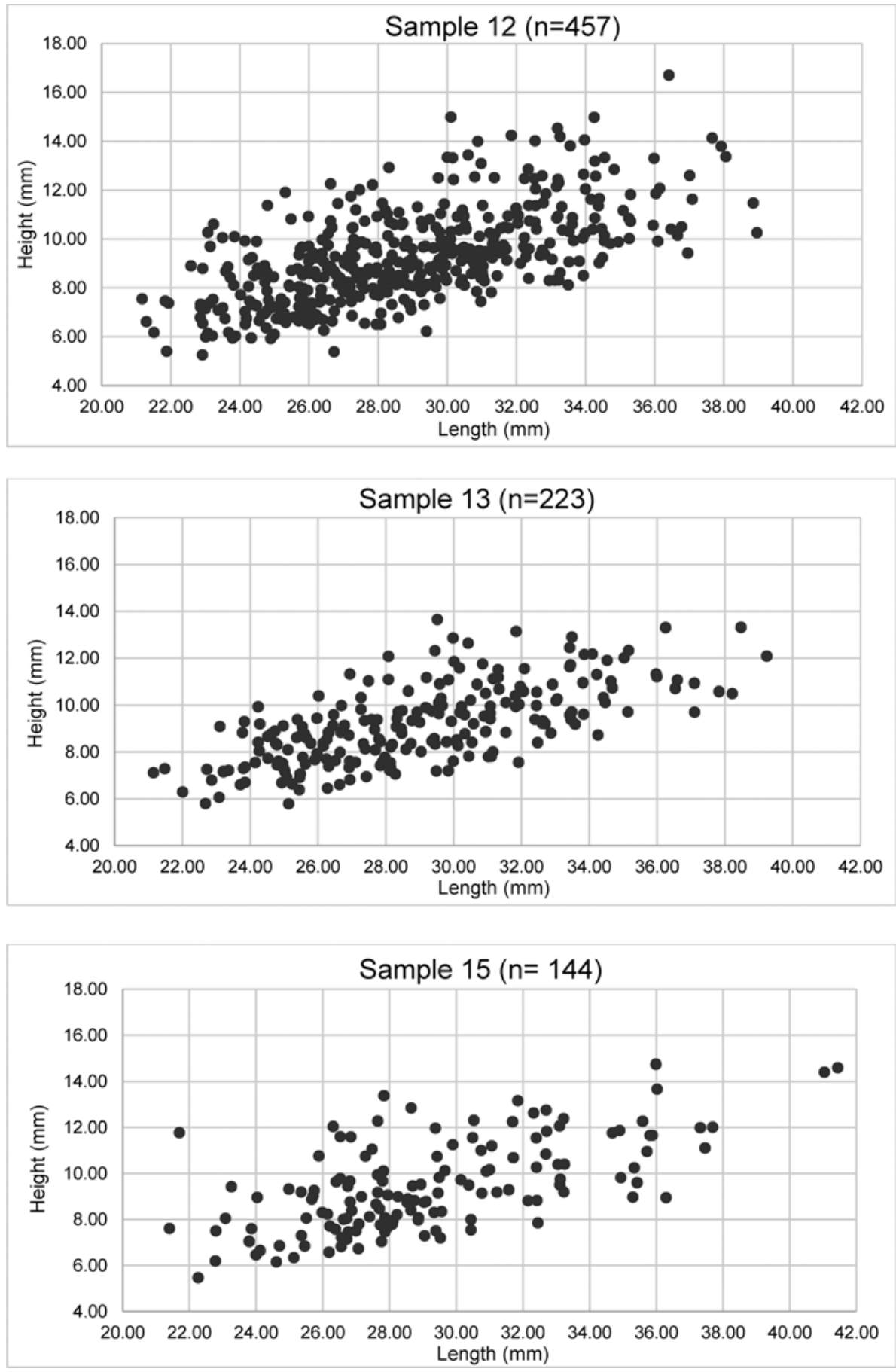

Fig. 10.

Scattergrams of limpet shell size dimensions from main 007 midden samples (after Winton 2018) 
strand considers the wider implications of Port Lobh for inter-island regional models of later Mesolithic occupation and the Mesolithic-Neolithic transition.

\section{Gathering practices on a dark tide}

Our current understanding of sea-level reconstruction is that the midden at Port Lobh, when formed, was situated above the contemporaneous shore and a few metres above the limit of the then high tides. At the time of occupation, woodland in the vicinity is probable and indirectly supported by the composition of the species from the macroplant and charcoal samples. Previous palynological studies for Colonsay suggest the likelihood of birch-hazel scrub with some mixed oak and elm cover during this period (Andrews et al. 1987).

Most of the identified fish remains are immature saithe and the species profile suggests the predominant use of nets, fixed facilities, and traps although the use of lines cannot be entirely ruled out. The medium-large sized cod is spatially and chronologically discrete and likely to represent a separate catch and processing event. It is also unburnt and contrasts with cod bones from the main midden deposits which are of smaller-sized specimens. The size of the cod suggests the use of lines probably from near-shore or, at most, inshore boat fishing (Pickard \& Bonsall 2004; Cerón-Carrasco 2005).

Limpets and periwinkles are the dominant shellfish species but these are also the most durable. The potential contribution of other species such as mussel, oyster, and razor shell should also be acknowledged. Prevailing cultural attitudes towards limpets and their identification as 'famine food' has also significantly conditioned archaeological consideration of this species as unpalatable and as a food of last resort (Fenton 1978; Mellars 2004; Milner 2009a). Notwithstanding the value of limpet meat as fish bait in other regions, limpets, razor clams, sea urchin, and other species are contemporary delicacies - eaten raw or prepared in a variety of ways. At Port Lobh, it appears likely that shellfish was gathered for human consumption as well as bait, although we cannot readily distinguish between uses. A range of shell sizes is present and by inference both mature and juvenile limpets and periwinkles present in most samples.

Limpets with a smooth exterior predominate but Patella specimens with ribbed exterior are also present albeit in smaller amounts (Table 8). The shape morphology of the limpets suggests collection from a range of tidal conditions and collection that includes the more exposed conditions of the lower tidal shore area during which time other resources such as crab and sea urchin could also be gathered. Further analysis of the shellfish assemblage and seasonality signatures at the site is ongoing. Elements of autumn/winter collection are suggested by the saithe otolith thin-section analysis. In the winter months collection at low tide in this latitude would take place in the dark or often in limited light conditions most of the time which may also influence size profiles especially for periwinkles, for these may have been scraped off the rocks into containers than individually hand-picked. The preliminary results from the saithe otolith work and fish size profile support fishing towards the end of the calendar year. In this respect the site is most similar to the Priory Midden - the only Oronsay midden site identified on the Atlantic west coast (Mellars 1987, 182-91). It too produced seasonality indicators for fishing late in the year, although caveats apply here with regards to seasonality indicators and the use of otolith length measurements (Mellars \& Wilkinson 1980) and the chronological overlap of the Oronsay middens (Wicks et al. 2014). Traditionally this period is seen as one of low resource availability but we have little current understanding of how communities provisioned for the winter months when certain sea resources were abundant.

Mussels were also gathered at Port Lobh and here it is difficult to evaluate their relative contribution given the propensity of these shells to disintegrate. Other species present in small quantities include oyster, whelk, scallop, and razor shell. The few fragmentary dog whelk shells were likely gathered alongside the other species for eating, if not bait. Commercially exploited in the historic past as a dye source, these creatures produce traces of a distinctive colour from mucus in a gland at the apex of the shell which changes to purple and red on exposure to light (Gibbons \& Gibbons 2004). It seems unlikely that it represents discrete and focused collection for significant use as a colorant here given low species representation. The flat peri winkle shell may have been accidentally collected in seaweed, rather than deliberately picked up for its colour-ful (yellow, green, red) shell, likewise the top shells. There is no indication of the use or deliberate modification of any of the Port Lobh shells seen at other middens (Bishop 1914; Mellars 1987; Hardy \& Wickham-Jones 2009), but only a small sample of midden deposit was investigated.

Other coastal seafoods such as unburnt sea urchin and, notably, crab were present as burnt fragments throughout the main midden. Cancer pagurus may 


\section{N. Finlay et al. REVISING SETTLEMENT MODELS, MESOLITHIC-NEOLITHIC TRANSITION, W. SCOTLAND}

also have been collected using traps and creels or gleaned from rockpools or crevices at low tide at the same time as shellfish collection. Though found at all the Oronsay sites (Mellars 1978), archaeologically crabs are a somewhat overlooked food source (Milner 2009b); the same is true for other marine resources such as algae/seaweed and sea urchin (Gutierrez-Zugasti et al. 2016).

At Port Lobh, the preservation of excavated mammal bone was limited to burnt or tiny fragments. For other terrestrial resources the small quantities of burnt hazelnut shell fragments are more suggestive of snacks (cf. Woodman et al. 1999) than debris indicative of larger-scale processing events or nut fuel caching like that evident at Staosnaig - a settlement on the east coast of the island with evidence for extensive hazelnut exploitation c. 6700-6400 cal BC (Mithen \& Finlay 2000; Mithen et al. 2001). The willow charcoal may represent the burning of old containers or wands generated from the repair or construction of creels, traps or other forms of basketry as it is a comparatively poor fuel.

\section{The Oronsay middens: monumental entities or fortuitous biographies?}

Much has been written about the potential monumental character of the Oronsay middens based on the appearance of Caisteal nan Gillean I as it was encountered in the 1880s and mistaken for a burial mound (Grieve 1923; Cummings 2003). The visibility of the white shells from other islands and out at sea is a dimension often discussed in relation to their potential role as navigational and identity markers (Pollard, T. 1996; Pollard, J. 1999; Finlay 2004). There has even been speculation about the (fortuitous) resemblance of the mounds to the profile of a limpet shell (Mellars 2004, 181). The extent to which these deposits constituted striking monumental entities in the landscape is, however, debatable (Warren 2007). Eroded at high tide, with developed palaeosoils, the reflective white deposits may not have stayed that way for very long. Deposits would become colonised by vegetation and, grassed over, the middens may have appeared more verdant, enriched by the underlying calcium and nutrient rich deposits and, in turn, became attractive, sought-out locales for subsequent cultivation (Guttmann 2005). Vegetation enrichment is a prospection aid for locating ancient middens in Tierra del Fuego (Piana \& Orquera 2010, 268) and may have wider application. The Oronsay middens were frequently referred to as 'green mounds' (Grieve 1923, 45) and the excellent pasture on Oronsay for cattle long noted (Loder 1935).

There are several significant factors that account for the preservation of the Oronsay midden sites. Salient among these are locational affordances, the persistent of place (after Schlanger 1992), and notable processes of isostatic uplift (Jardine 1978). Another key factor overlooked in most discussions is the contributory role of the unusual land tenure of Oronsay and the afterlives of these sites. The ecclesiastical significance of the island, from at least the early 14th century AD with the surviving priory, as a place of worship, sanctuary and, significantly, burial gave continuity across the centuries in subsequent modes of land use. After the Reformation, it remained an important burial centre - beyond its significance as the ancestral burial ground of the Macfies of Colonsay. This fact precluded significant ground disturbance through ploughing well into the early 20th century (Grieve 1923, 288). Indeed, recent dating of isolated human bones from earlier excavations has produced various medieval dates (Sheridan et al. 2017).

During the period of the Napoleonic wars, Colonsay was well-known for the use and export of seaweed fertiliser and this combined with the productive richness of the Oronsay grass and enhanced export market for cattle may also have afforded greater protection of the shell middens. Elsewhere, agricultural improvement led to significant shell midden destruction at a time when their archaeological importance was beginning to be recognised (Movius 1942; Andersen 2007). The propensity for aeolian erosion of the sand covered shell mounds was accelerated by the agency of rabbits (introduced to the islands from the 1750s) and appears significant at Port Lobh. Even Grieve, in his 1881 excavations at Caisteal nan Gillean on Oronsay, recognised rabbits as a destructive force and, equally, as key agents in the exposure of archaeological remains such as Norse burials (see also McNeill 1891).

In fact, the survival of the Oronsay middens may owe much to the subsequent history of the island and to prevailing folklore tradition that countenanced site exploration and destruction (Grieve 1923). The other key factor that has elevated their significance has been the prolonged archaeological gaze which has perpetuated the importance of these sites at the expense of others. Similar and less well explored shell middens exist on other islands notably Risga (Pollard 2000) and Rum 
(Wickham-Jones 1993). Others of comparable date survive beneath chambered cairns, eg, Crarae, Argyll (Schulting \& Richards 2002) and Glecknabae, Bute (Bryce 1904). Rescue excavation (Saville et al. 2012) and systematic regional archaeological survey notably the work of Scotland's First Setters project has identified numerous shell middens of all periods and high prehistoric scatter site densities (Hardy \& Wickham-Jones 2002; 2009). Therefore, while the Oronsay middens are significant sites, particularly in the historiography of the European Mesolithic, does it pay to continue to see them as unique and exceptional?

\section{Port Lobh and Oronsay: models of Late Mesolithic sedentism}

Two opposing settlement models have been proposed for the Oronsay sites. The first is that the middens are created through transient or seasonal occupation by individuals based largely elsewhere (eg, Mithen \& Finlayson 1991). The other argues for a (semi-)permanent population on Oronsay exploiting coastal resources. It was based on interpretation of the saithe otolith length data from the 1970s excavations (Mellars \& Wilkinson 1980; Mellars 2004) and proposes that groups moved around Oronsay sites and spent most, if not all, of the year on that island. The premise of Oronsay sedentism was built on the evidence from the saithe otolith length data which now needs critical re-evaluation in the light of more advanced thin-section techniques and processes of temporal conflation of midden activity in the original model. Subsequent marine stable isotope results on human remains from Cnoc Coig re-opened the debate about sedentism and led to the proposition that occupation on Oronsay might even have been permanent (Richards \& Mellars 1998; see also Mithen 2000a; Mithen et al. 2007).

In discussion of the permanent and semi-sedentary models of settlement, the arguments that groups avoided the rich resources on Colonsay - accessible on foot via low tide - have never been convincing on subsistence grounds alone. Neither have the social imperatives to remain solely on Oronsay and cultural proscriptions would need to be profound to have limited gatherer-hunter occupation permanently to the smaller island with little evidence, as yet, to suggest that this was necessitated by external factors. At high tide the short sea crossing to Colonsay is not significant given other evidence of sea-faring craft and inter-island movement - even with more variable sea conditions (Garrow \& Sturt 2011).

The absence of archaeological evidence on Colonsay has been taken for a genuine absence of occupation focus. Yet, there are other indications of contemporaneous occupation on the larger island. At Staosnaig, for example, where a 4370-4060 cal $\mathrm{BC}$ date $(5415 \pm 60 \mathrm{BP}, \mathrm{AA}-21629)$ was returned on charred hazelnut shell from the upper layer of an isolated pit containing microliths, platform and bipolar cores in the lower deposits (Mithen \& Finlay 2000, 390). While the lithic finds are likely an earlier separate event, this date points to a discrete fire using hazelnut shell fuel during this period. Comparable radiocarbon dates from the recent excavations at Storakaig, Islay also offers evidence for the exploitation of terrestrial resources that countenance the predominately maritime subsistence focus associated with this period (Mithen \& Wicks 2010; Wicks et al. 2014). Bayesian re-evaluation of the midden chronologies also significantly challenges the likelihood of year round settlement on Oronsay (Wicks et al. 2014, table 5) and the new Port Lobh dates chronologically overlap with those now modelled for the duration of accumulation of the Oronsay sites.

While Port Lobh is the first open air shell midden site to be excavated on Colonsay, it is unlikely to be the only site of this period to survive (cf. Lacaille 1954, 298). Its presence means that we need to consider occupation on Colonsay and revisit the apparent unique status of the Oronsay middens in regional settlement and subsistence models.

A key factor conditioning the identification of former midden sites is the character of the lithic assemblage with ongoing debate over technological continuity and the chronological relationship with microlith rich sites (Wicks et al. 2014). At Port Lobh, and at most of the Oronsay middens, chipped stone artefacts are the result of bipolar reduction; most are simple flakes, chunks and debitage. As simple direct platform percussion and bipolar techniques continued there has been a tendency to attribute surface finds of this character to later prehistoric periods. This ignores the potential significance of these forms of stone-working practices and for low-density scatters or individual chance finds to be indicative signatures of 5 th- 4 th millennium cal BC activity. The discovery of these simple unmodified artefacts in dated midden deposits, as on Oronsay, has been explained as functional expediency (Bonsall 1997) rather than recognition of their potential utility as an 


\section{N. Finlay et al. REVISING SETTLEMENT MODELS, MESOLITHIC-NEOLITHIC TRANSITION, W. SCOTLAND}

indicator for identifying former shell midden/settlement sites of this period. Without shell preservation and a midden to provide a context isolated pieces or surface scatters are overlooked. While re-evaluation of the lithic material from the Oronsay sites (Pirie et al. 2006; Wicks et al. 2014) is welcomed, and augments regional understandings of technological change, the shift towards assemblages with fewer pieces and characterised by direct percussion and bipolar strategies is more widespread. The chronological complexities and palimpsest nature of many shell midden sites are challenging, as are patterns of lithic scavenging and site re-use. Adopting more chronologically sensitive and paying detailed attention to the local circumstances should elucidate much about trends in lithic use and enhance new site recognition.

One of the recurrent tropes in discussions of the wider significance of the Oronsay middens is their relation to the Mesolithic-Neolithic transition. The crux of the debate is whether the Oronsay middens represent the continuation of local maritime Mesolithic lifeways. Alternatively, are they remnants from a potentially marginalised indigenous population, aware of and responding to, fundamental changes resulting from contact with Neolithic 'others' with novel material culture, beliefs, and agricultural practices? (For various interpretations see Schulting \& Richards 2002; Whittle \& Cummings 2007; Sheridan 2010; Sheridan $\&$ Pétrequin 2014). The Mesolithic status of the Oronsay midden sites has been called into question given the new dating evidence that is coterminous with the adoption of agriculture that was well-established elsewhere in western Scotland by $3800 \mathrm{cal} \mathrm{BC}$ and in southern Britain from the 41st century cal BC (Whittle et al. 2011), although their dating, like our use of terminology, is problematic. More single entity dates are needed from these sites rather than reliance on older mixed charcoal dates and a wider perspective drawn from other regional evidence.

Should Colonsay therefore be seen as a regional Neolithic 'no-go' zone with Oronsay a central place of indigenous Mesolithic occupation? Neolithic material culture is elusive on Colonsay, comprising four stone axeheads, including one of porcellanite from fieldwalking at Machrins (Mithen 2000c, 353), and several leafshaped arrowheads from Oronsay (Wickham-Jones et al. 1982). Excavations at a putative chambered cairn above Loch Fada failed to establish date or function (Mithen 1991, 23-7). Evidence is better attested on neighbouring Islay in terms of monuments and, more critically, settlement evidence which includes the precairn horizon at Port Charlotte chambered cairn (Harrington \& Pierpoint 1980) and the more substantial evidence at Newton with fence enclosures and pits. Charcoal from one pit containing carinated pottery dates to 3940-3640 cal BC (McCullagh 1989). Yet the inter-island dynamics of settlement during this period are subject to transformation with the next new discovery, as aptly demonstrated by Port Lobh, and opinion has oscillated based on the available evidence (Mithen 2000a; Wicks et al. 2014).

The apparent cultural rejection of marine resources in the diet that ensued with the adoption of agriculture has been subject to much debate that need not directly concern us here (eg, Milner et al. 2004; Richards and Schulting 2006). Marine stable isotope data indicate that parts of individuals with different subsistence strategies are found in the Oronsay midden sites. Conflicting impressions from stable isotope analysis on human bone indicates a diet dominated by marine protein for individuals at Cnoc Coig, recalibrated to 4250-3650 cal BC (Milner \& Craig 2009) and among more recently identified human bone fragments from the site (Charlton et al. 2016). One individual at Casteal Nan Gillean II has a mixed terrestrial and marine protein diet (Richards \& Mellars 1998; Richards \& Sheridan 2000). While the signature from one of the Cnoc Coig individuals suggests an extreme dietary reliance on coastal resources, all this work does not, however, address issues of residency as opposed to diet.

At Cnoc Coig, the most extensively excavated Oronsay shell midden site, there is also earlier structural evidence, dense hazelnut shell rich deposits and evidence for 'dirty' processing of carcasses and hides (Finlayson 2000, 263) in addition to concentrated shell midden deposits. The cultural saliency of the sea is a dominant motif in the Oronsay shell midden sites and its ideological significance read in the layering of marine shells, human digits, and seal flippers at Cnoc Coig (Meikejohn et al. 2005). The character of the lower structural remains at this site are more suggestive of life crisis rituals beyond those associated with death. The presence of ochre and perforated shells is notable the smaller cowries used for adornment or decoration while some of the larger perforated scallops might better be interpreted as rattles for dancing or other performative acts. Worldwide, coastal resources offer a reliable supply of foodstuffs that have enabled group aggregation to take place and provide opportunities for initiation and other ceremonial rites to occur. 
It is evident that the Oronsay sites serve as a nexus for a range of activities at different times of the year and through time in more complex ways than suggested by the stasis of a cyclical intra-island settlement model.

Shellfish collection is often considered to be a subsistence activity undertaken primarily by women and children and denigrated as a result. Yet it represents a dependable food source rich in essential minerals, readily accessible by the young, the elderly, and less-mobile members of a community (Meehan 1982; Bird \& Bliege Bird 2000). The social dynamic and composition of groups creating the Oronsay sites is discussed solely in abstract terms in the context of 'breeding networks' (Mellars 2004, 179). The impact of group size and composition on interpretations of the middens and for understandings of task scheduling are significant and challenging. Addressing these aspects highlights the constraints of current archaeological interpretations, especially how different depositional events and practices are conflated at sites with archaeological attention focused at the macro- rather than the micro-scale. Refocusing on the intimacies of action represented by these deposits in lived time enables us to consider the interplay of coastal resources and the experience of island communities within these wider temporal frames. This is critical if we are to move beyond the more essentialising narratives of subsistence/settlement models that fail to get to the heart of the issues.

\section{CONCLUSIONS}

Is it, therefore, time to draw a line under debates about Oronsay sedentism/mobility? Moving on requires new perspectives on these sites and the reframing of future research questions. In this respect, Port Lobh is a welcome and valuable addition to the increasing corpus of sites that document the character of coastal living along the Scottish western seaboard. At this location in western Colonsay ashes and cooking stone from fires were discarded, fish gutted, and crab and other foods prepared - a place where these actions accumulated above the shore. The available evidence suggests that these activities and the likely occupation events they relate to may have focused predominately in the latter half of the year and into the dark mid-winter months, but other seasonality signatures are present. The practices undertaken reference wider and enduring traditions of coastal fishing and shore gathering. At Port Lobh, these actions are the same as those taking place on neighbouring Oronsay and resonate with other regional caves and rock-shelter deposits further afield like Ulva Cave, off Mull (Bonsall 1997; Russell et al. 1995) and Sand, Applecross (Hardy \& Wickham-Jones 2009). Bayesian modelling and reevaluation of the radiocarbon dates from the Oronsay middens, which are problematic due to bulk samples, old wood, marine reservoir effects, and calibration curve plateau, demonstrate chronological overlap with the earliest Neolithic in the region and gathering practices at different sites like Port Lobh and Storakaig, Islay (Wicks \& Mithen 2014; Wicks et al. 2014). Precision still evades us within the critical timeframe of the centuries surrounding the transition and in untangling the stratigraphic challenges of these complex midden sites, as seen at Port Lobh, in terms of dating resolution of accumulation events. Yet it is clear we need more sensitive methodological strategies and more responsive models.

Geophysical survey methodologies have considerable potential to enhance the identification and characterisation of shell middens and other huntergatherer sites as a research and management tool. Repeat surveys, wider experimentation using finer sampling intervals, and creating new modes of enhanced precision for data interrogation/presentation specifically to interpret more subtle prehistoric feature responses are needed for future applications to build on the work at Port Lobh and that seen recently at other European sites (Arias et al. 2017). At the same time, theoretical attention needs to be directed to how we approach key issues around residency and cohabitation in land and seascapes for subsistence models especially around the transition. Perhaps we do need to call time altogether on the entrenched debates about resolving questions of mobility versus sedentism on Oronsay to consider other dynamics around the lived experience and the seasonal practices represented by shell middens like Port Lobh and the attraction of places like Oronsay.

To conclude, while we do not yet know whether the people at Port Lobh were the same folk or even kin of those responsible for creating some of the Oronsay midden deposits, the dates as well as proximity and similarity of depositional practice indicate that this is an intriguing probability. As the first shell midden to be dated to this period on Colonsay, Port Lobh is significant for reframing the debate about the role of the Oronsay midden sites within regional settlement and subsistence models and their place in the wider 


\section{N. Finlay et al. REVISING SETTLEMENT MODELS, MESOLITHIC-NEOLITHIC TRANSITION, W. SCOTLAND}

European context of the Mesolithic-Neolithic transition. Further mound sites remain to be explored on Colonsay and looking beyond Oronsay itself may ultimately enable us to understand more about lifeways on this and adjacent islands during what we now recognise as a significant and dynamic era of change. More fundamentally through, we need to explore and embrace more creative and riskier fieldwork strategies to recognise new sites and address alternative research questions if the tide of academic debate is to more profitably turn.

Acknowledgements: This paper is dedicated to the memory of W. Graham Jardine. Fieldwork was supported by small research grants from the British Academy (SG40312), and the Society of Antiquaries of Scotland to NF. The support of Archaeology at the University of Glasgow is also gratefully acknowledged. Historic Scotland funded some of the radiocarbon dates. NF is very grateful to Alexander Howard, Lord Strathcona, Colonsay Estates; Seamus McNeill, and the Colonsay Golf Club for permission to excavate and for information about the site and to David Jardine for information from family archives. Thanks to the survey and excavation team of Natalie Bergman, John Malcolm, and Andrea Jackson, for their hard work and good company as well as the essential contributions of Paul and Rosie Duffy. Thanks also to Ernesto Piana who offered valuable discussion and advice; Morgana McCabe and Gavin Baker for their outstanding work on the post-excavation processing; Tessa Poller for stepping in to process the geophysical survey data and Anna Winton for further shell studies. The site illustrations and artefact drawings are the work of Gill Sneddon, Alice Watterson, Lorraine McEwan, and Nyree Finlay. The text has been improved by the perceptive comments of critical friends among them Paul Duffy and Michael Given, and the anonymous reviewers. The site archive is deposited with the National Record of The Historic Environment, Historic Environment Scotland, Edinburgh.

\section{BIBLIOGRAPHY}

Andersen, S.H. 2007. Shell middens ('Køkkenmøddinger') in Danish prehistory as a reflection of the marine environment. In N. Milner, O.E. Craig, and G.N. Bailey (eds), Shell Middens in Atlantic Europe, 31-45. Oxford: Oxbow Books Anderson, J. 1898. Notes on the contents of a small cave or rock-shelter at Druimvargie, Oban; and of three shellmounds in Oronsay. Proceedings of the Society of Antiquaries of Scotland 32, 298-313

Andrews, M.V., Gilbertson, D.D. \& Kent, M. 1987. Storm frequencies along the Mesolithic coastline. In Mellars 1987, 108-14

Andrews, M.V., Beck, R.B., Birks, H.J.B. \& Gilbertson, D.D. 1987. The past and present vegetation of Oronsay and Colonsay. In Mellars 1987, 52-77

Arias, P., Diniz, M., Cubas, M., Duarte, C., Iriate, E., Salzmann, C., Teichner, F. \& Teira, L. 2017. Looking for the traces of the last hunter-gatherers: Geophysical survey in the Mesolithic shell middens of the Sado valley (southern Portugal). Quaternary International 435, 61-70

Barrett, J.H., Nicholson, R.A. \& Cerón-Carrasco, R. 1999. Archaeo-icthyological evidence for long-term economic trends in northern Scotland: $3500 \mathrm{BC}$ to $1500 \mathrm{AD}$. Journal of Archaeological Science 26(4), 353-88

Baxter, J.M. 1982. Population dynamics of Patella vulgata in Orkney. Netherlands Journal of Sea Research 16, 94-104

Becket, A. \& Batey, C.E. 2013. A stranger in the dunes? Rescue excavation of a Viking Age burial at Cnoc nan Gall. Colonsay. Proceedings of the Society of Antiquaries of Scotland 143, 303-18

Birch, S. 2009. The production and use of bone bevel ended tools. In Hardy \& Wickham-Jones 2009, www.sair.org. uk/sair31/sections3-4.html

Bird, D.W. \& Bliege Bird, R. 2000. The ethnoarchaeology of juvenile foragers: shellfishing strategies among Meriam children. Journal of Anthropological Archaeology 19, 461-76

Bishop, A.H. 1914. An Oronsay shell-mound - a Scottish pre-Neolithic site. Proceedings of the Society of Antiquaries of Scotland 48, 52-108

Bonsall, C. 1997. Coastal adaptation in the Mesolithic of Argyll. Rethinking the 'Obanian' problem. In G. Ritchie (ed.), The Archaeology of Argyll, 25-37. Edinburgh: Edinburgh University Press

Boyd, J.M. \& Boyd, I.L. 1996a. The Hebrides: A habitable land. Edinburgh: Birlinn

Boyd, J.M. \& Boyd, I.L. 1996b. The Hebrides: A natural tapestry. Edinburgh: Birlinn

Branch, G.M. 1985. Limpets: Their role in littoral and sublittoral community dynamics. In Moore \& Seed 1985, 97-116

Bronk Ramsey, C. 2009. Bayesian analysis of radiocarbon dates, Radiocarbon 51(1), 337-60

Bryce, T.H. 1904. On the cairns and tumuli of the Island of Bute. A record of explorations of the season of 1903. Proceedings of the Society of Antiquaries of Scotland 38, 17-81

Campbell, A.C. \& Nicholls, J. 1989. Seashores \& Shallow Seas of Britain and Europe. London: Hamlyn Guides

Campbell, G. 2008. Beyond means to meaning: Using distributions of shell shapes to reconstruct past collecting strategies. Environmental Archaeology 13, 111-21

Cerón-Carrasco, R.N. 2005. 'Of Fish and Men' (De iasg agus dhaoine): Aspects of the utilization of marine resources as recovered from selected Hebridean archaeological sites. Oxford: British Archaeological Report 400

Cerón-Carrasco, R. 2006. The marine molluscs with notes on the Echinoidea remains and the terrestrial snails. In I. Armit (ed.), Anatomy of an Iron Age Roundhouse: The Cnip wheelhouse excavations, Lewis, 180-2. Edinburgh: Society of Antiquaries of Scotland

Cerón-Carrasco, R. 2008. Port Lobh, Colonsay: Terrestrial molluscs. Unpublished archive report, University of Glasgow

Charlton, S., Alexander, M., Collins, M., Milner, N., Mellars, P., O'Connell, T.C., Stevens, R.E. \& Craig, O.E. 2016. Finding Britain's last hunter-gatherers: A new biomolecular 
approach to 'unidentifiable' bone fragments utilising bone collagen. Journal of Archaeological Science 73, 55-61

Clarke, A. 1990. Coarse stone tools. In C.R. Wickham-Jones (ed.), Rhum: Mesolithic and later sites at Kinloch, excavations 1984-6, 117-26. Edinburgh: Society of Antiquaries Monograph 7

Clarke, A. 2009. Craft specialisation in the Mesolithic of northern Britain: the evidence from the coarse stone tools. In N. Finlay, S. McCartan, N. Milner, and C. WickhamJones, (eds), From Bann Flakes to Bushmills: Papers in honour of Professor Peter Woodman, 22-30. Oxford: Prehistoric Society Research Paper 1

Cummings, V. 2003. The origins of monumentality? Mesolithic world-views of the landscape in western Britain. In L. Larsson, H. Kindgren, H. Knutsson, D. Loefller, and A. Akerlund (eds), Mesolithic on the Move, 74-81. Oxford: Oxbow Books

Fenton, A. 1978. The Northern Isles: Orkney and Shetland. Edinburgh: John Donald

Finlay, N. 1997. The Lithic Assemblage from Cnoc Coig, Oronsay. Unpublished report, University of Reading

Finlay, N. 2004. E-scapes and E-motion: other ways of writing the Mesolithic. Before Farming 2004(1) article 4. DOI: 10.3828/bfarm.2004.1.4

Finlay, N. \& Jardine, G. 2015. Lithic artefacts and the availability of pebble-flint on Colonsay, Scottish Inner Hebrides, in relation to coastal changes. Scottish Archaeological Journal 36, 37-50

Finlay, N. \& McAllen, L. 2009. 3, 17 Geophysical survey at Sand, Applecross. In Hardy \& Wickham-Jones 2009, 423-6

Finlay, N., Warren, G. \& Wickham-Jones, C.R. 2004 The Mesolithic in Scotland: east meets west Scottish Archaeological Journal 24(2) (2002): 101-20

Finlay, N.Campbell, E., Cerón-Carrasco, R., Housley, R., Huggett, J. \& Smith, C. 2019. Iron Age occupation evidence from Port Lobh, Colonsay (Scottish Inner Hebrides). Scottish Archaeological Journal 41, 119-23

Finlayson, B. 1995. Complexity in the Mesolithic of the western Scottish seaboard. In A. Fischer (ed.) 1995. Man and Sea in the Mesolithic: Coastal Settlement Above and Below Present Sea Level, 261-4. Oxford: Oxbow Monograph 53

Finlayson, B., Finlay, N. \& Mithen, S. 2000. The cataloguing and analysis of the lithic assemblages. In Mithen, (ed.) 2000b, 61-74.

Garrow, D. \& Sturt, F. 2011. Grey waters bright with Neolithic Argonauts? Maritime connections and the Mesolithic-Neolithic transition within the 'western seaways' of Britain, c. 5000-3500 BC. Antiquity 85, 59-72

Gibbons, M. \& Gibbons, M. 2004. Dyeing in the Mesolithic. Archaeology Ireland 17, 28-31

Grieve, S. 1923. The Book of Colonsay and Oronsay. Edinburgh: Oliver \& Boyd

Grigson, C. \& Mellars, P. 1987. The mammalian remains from the middens. In Mellars 1987, 243-89

Gutierrez-Zugasti, I., Tong, E., García-Escarzaga, A., Cuenca-Solana, D., Bailey, G.N. \& Gonzalez-Morales, M.R. 2016. Collection and consumption of echinoderms and crustaceans at the Mesolithic shell midden site of El Mazo (northern Iberia): Opportunistic behaviour or social strategy? Quaternary International 407, 118-30

Guttmann, E.B.A. 2005. Midden cultivation in prehistoric Britain: arable crops in gardens. World Archaeology 37(2), 224-39

Hardy, K. \& Wickham-Jones, C.R. 2002. Scotland's first settlers: the Mesolithic seascape of the Inner Sound, Skye and its contribution to the early prehistory of Scotland. Antiquity 76, 825-33

Hardy, K. \&Wickham-Jones, C.R. (eds). 2009. Mesolithic and Later Sites Around the Inner Sound, Scotland the Work of the Scotland's First Settlers project 1998-2004. Edinburgh: Society of Antiquaries of Scotland. doi: 10. 5284/1017938

Harkness, D.D. 1983. The extent of the natural 14C deficiency in the coastal environment of the United Kingdom. Journal of the European Study Group on Physical, Chemical and Mathematical Techniques Applied to Archaeology PACT 8(IV.9), 351-64

Harrington, S. \& Pierpoint, P. 1980. Port Charlotte chambered cairn, Islay: An interim note. Glasgow Archaeological Journal 7, 113-5

Hislop, J., Bergstad, O., Jakobsen, T., Sparholt, H., Blasdale, T., Wright, P., Kloppmann, M., Hillgruber, N. \& Heesen, H. 2015. Cod fishes (Gadidae). In H. Heesen, N. Daan, and J. Ellis, (eds), Fish Atlas of the Celtic Sea, North Sea and Baltic Sea, 186-236. Zeist: KNNV

Hylleberg, J. \& Christensen, J.T. 1977. Phenotypic variation and fitness of periwinkles (Gastropoda: Littorinidae) in relation to exposure. Journal of Molluscan Studies 43, 192-9

Jardine, W.G. 1978. Radiocarbon ages of raised-beach shells from Oronsay, Inner Hebrides, Scotland: a lesson in interpretation and deduction. Boreas 7, 183-96

Jardine, W.G. 1987. The Mesolithic coastal setting. In Mellars 1987, 25-51

Jones, A.M. \& Baxter, J.M. 1985. The use of Patella vulgata L. in rocky shore surveillance. In Moore \& Seed 1985, 265-73

Kitching, J.A., Muntz, L., \& Ebling, F.J. 1966. The ecology of Lough Ine. XV. The ecological significance of shell and body forms on Nucella. Journal of Animal Ecology 35, 113-26

Lacaille, A.D. 1951. A stone industry from Morar, Inverness-shire; its Obanian (Mesolithic) and later affinities. Archaeologia 94, 103-39

Lacaille, A.D. 1954. The Stone Age in Scotland. Oxford: Oxford University Press

Loder, J. 1935. Colonsay and Oronsay in the isles of Argyll: Their history, flora, fauna and topography. Edinburgh: Oliver \& Boyd

McCullagh, R. 1989. Excavations at Newton, Islay. Glasgow Archaeological Journal 15, 23-51

McNeill, M. 1891. Notice of excavations in a burial mound of Viking Time in Oronsay. Proceedings of the Prebistoric Society 25, 432

McNeill, M. 1910. Colonsay, one of the Hebrides, its plants: their local names and uses - legends, ruins and placenames- Gaelic names of birds, fishes, etc. - climate, geological formation, etc. Edinburgh: David Douglas 


\section{N. Finlay et al. REVISING SETTLEMENT MODELS, MESOLITHIC-NEOLITHIC TRANSITION, W. SCOTLAND}

Macleod, S. \& Gordon, D. 2006. Colonsay Airfield, Isle of Colonsay: archaeological mitigation. Data Structures Report. Rathmell Archaeology Ltd: unpublished report

Marshall, G. 2000. The distribution of beach pebble flint in Western Scotland with reference to raw material use during the Mesolithic, In Mithen 2000b, 75-77

Meehan, B. 1982. From Shell Bed to Shell Midden. Canberra: National Australian Institute of Aboriginal Studies

Meiklejohn, C., Merrett, D.C., Nolan, R.W., Richards, M.P. and Mellars, P.A. 2005. Spatial relationships, dating and taphonomy of the human bone from the Mesolithic site of Cnoc Coig, Oronsay, Argyll, Scotland. Proceedings of the Prehistoric Society 71, 85-105

Mellars, P. 1978. Excavation and Economic Analysis of Mesolithic Shell Middens on the Island of Oronsay. In P. Mellars (ed.) The Early Postglacial Settlement of Northern Europe: An Ecological Perspective, 371-96 London: Duckworth

Mellars, P. (ed.) 1987. Excavations on Oronsay: prehistoric buman ecology on a small island. Edinburgh: Edinburgh University Press

Mellars, P. 2004. Mesolithic Scotland, Coastal Occupation and the role of the Oronsay middens. In Saville 2004, 167-183

Mellars, P. A. \& Wilkinson, M. R. 1980. Fish otoliths as indicators of seasonality in prehistoric fish middens: the evidence from Oronsay (Inner Hebrides). Proceedings of the Prehistoric Society 46, 19-44

Milner, N. 2009a. 3.12. Mesolithic middens and marine molluscs: procurement and consumption of shellfish at the site of Sand. In Hardy \& Wickham-Jones 1990, 384-400

Milner, N. 2009b. 3.13. Consumption of crabs in the Mesolithic: side stepping the evidence? In Hardy \& Wickham-Jones 2009, 401-7

Milner, N. \& Craig, O.E. 2009. Mysteries of the Middens; change and continuity across the Mesolithic-Neolithic transition. In M.J. Allen, N. Sharples, and T. O'Connor, (eds), Land and People: Papers in memory of John G Evans, 169-80. Oxford: Prehistoric Society Research 2

Milner, N., Craig, O.E., Bailey, G.N., Pedersen, K. \& Andersen, S.H. 2004. Something fishy in the Neolithic? A re-evaluation of stable isotope analysis of Mesolithic and Neolithic coastal populations. Antiquity 78, 9-22

Mithen, S. 1991. Excavations at Uaigh an Fhomair (The Giant's Grave). In S. Mithen, (ed.), Southern Hebrides Mesolithic Project Fourth (1991) Interim Report, 23-7. Unpublished report, McDonald Institute, Cambridge

Mithen, S. 2000a. Mesolithic sedentism on Oronsay: chronological evidence from adjacent islands in the Southern Hebrides. Antiquity 74, 298-304

Mithen, S. (ed.) 2000b. Hunter-Gatherer Landscape Archaeology: The Southern Hebrides Mesolithic Project 1988-98. Cambridge: McDonald Institute

Mithen, S. 2000c. The Colonsay survey. In Mithen 2000b, 349-59

Mithen, S. \& Finlay, N. 2000. Staosnaig, Colonsay: excavations 1989-1995. In Mithen 2000b, 359-441
Mithen, S. \& Finlayson, B. 1991. Red deer hunters on Colonsay? The implications of Staosnaig for the interpretations of the Oronsay middens. Proceedings of the Prehistoric Society 57, 1-8

Mithen, S. \& Wicks, K. 2010. Storakaig and Rubha Port an t-Seilich. Archaeological evaluation of new Mesolithic sites on Islay, western Scotland. Unpublished report, University of Reading.

Mithen, S., Pirie, A., Smith, S. \& Wicks, K. 2007. The Mesolithic-Neolithic transition in western Scotland: a review and new evidence from Tiree. In Whittle \& Cummings 2007, 511-41

Mithen, S., Finlay, N., Carruthers, W., Carter, S. \& Ashmore, P. 2001. Plant use in the Mesolithic: evidence from Staosnaig, Isle of Colonsay, Scotland. Journal of Archaeological Science 28, 223-34

Moore, P.G. \& Seed, R. (eds). 1985 The Ecology of Rocky Coasts. London: Hodder \& Stoughton

Moreno-Nuño, R. 1994a Arqueomalacología. Identificación de Moluscos. Informe no. 1994/18. Madrid: Universidad Autónoma de Madrid, Laboratorio de Arqueozoologia

Moreno-Nuño, R. 1994b. Arqueomalacología. Cuantificación de Moluscos. Informe no. 1994/19. Madrid: Universidad Autónoma de Madrid, Laboratorio de Arqueozoologia Madrid

Movius, H. 1942. The Irish Stone Age. Cambridge: Cambridge University Press

Nicholson, R.A. 1991. An Investigation into Variability Within Archaeologically Recovered Assemblages of Faunal Remains: The influence of pre-depositional taphonomic processes. Unpublished, D. Phil. Thesis, University of York Nolan, R.W. 1986. Cnoc Coig: The spatial analysis of a late Mesolithic shell midden in western Scotland. Unpublished PhD thesis, University of Sheffield

Piana, E.L. \& Orquera, L.A. 2010. Shell midden formation at the Beagle Channel (Tierra del Fuego, Argentine). In D. Calado, M. Baldia \& M. Boulanger, M. (eds), Monumental Questions: Prehistoric megaliths, mounds and enclosures, 263-71. Oxford: British Archaeological Report S2122

Pickard, C. \& Bonsall, C. 2004. Deep-sea fishing in the European Mesolithic: fact or fantasy? European Journal of Archaeology 7(3), 273-290

Pirie, A., Mellars, P.A. \& Mithen, S. 2006. Cnoc Coig: A Mesolithic shell midden assemblage. Lithics 27, 4-11

Pollard, J. 1999. Ancestral places in the Mesolithic landscape. Archaeological Review from Cambridge 17(1), 123-38

Pollard, T. 1996. Time and tide: coastal environments, cosmology and ritual practice in early prehistoric Scotland. In T. Pollard, and A. Morrison (eds), The Early Prehistory of Scotland, 198-213. Edinburgh: Edinburgh University Press

Pollard, T. 2000. Risga and the Mesolithic occupation of Scottish islands. In R. Young (ed.), Mesolithic Lifeways: Current research from Britain and Ireland, 143-52. Leicester: Leicester Archaeological Monograph Series 7

Reimer, P. J., Bard, E., Bayliss, A., Beck, J. W., Blackwell, P. G., Bronk Ramsey, C., Grootes, P. M., Guilderson, T. P., Haflidason, H., Hajdas, I., Hatt, C., Heaton, T. J., 
Hoffmann, D. L., Hogg, A. G., Hughen, K. A., Kaiser, K. F., Kromer, B., Manning, S. W., Niu, M., Reimer, R. W., Richards, D. A., Scott, E. M., Southon, J. R., Staff, R. A., Turney, C. S. M. \& van der Plicht, J. 2013. IntCal13 and Marine13 radiocarbon age calibration curves 0-50, 000 years cal BP, Radiocarbon, 55(4), 1869-87

Renfrew, J. 1993. Prehistoric food resources. In P. Brears, M. Black, G. Corbinshley, J. Renfrew, and J. Stead (eds). A Taste of History: 10,000 years of Food in Britain, 18. London: British Museum Press

Richards, M.P. \& Mellars, P.A. 1998. Stable isotopes and the seasonality of the Oronsay middens. Antiquity 72, 1178-84

Richards, M.P. \& Schulting, R.J. 2006. Against the grain? A response to Milner et al. (2004). Antiquity 80, 444-58

Richards, M.P. \& Sheridan, J.A. 2000. New AMS dates on human bone from Mesolithic Oronsay. Antiquity 74, 313-15

Ritchie, G. 1981. Excavations at Machrins, Colonsay. Proceedings of the Society of Antiquaries of Scotland $111,263-81$

Russell, N.J., Bonsall, C. \& Sutherland, D.G. 1995. The exploitation of marine molluscs in the Mesolithic of western Scotland: evidence from Ulva Cave, Inner Hebrides. A. Fischer (ed.) 1995. Man and Sea in the Mesolithic: Coastal Settlement Above and Below Present Sea Level, 273-87. Oxford: Oxbow Monograph 53

Saville, A (ed.) 2004. Mesolithic Scotland and its Neighbours: The Early Holocene prehistory of Scotland, its British and Irish context and some northern European perspectives. Edinburgh: Society of Antiquaries of Scotland

Saville, A., Hardy, K., Miket, R. \& Bjarke Ballin, T. 2012. An Corran, Staffin, Skye: a rockshelter with Mesolithic and Later Occupation. Scottish Archaeological Internet Report 51. doi: 10.5284/1017938

Schlanger, S.H. 1992. Recognizing persistent places in Anasazi settlement systems. In J. Rossignol, and L. Wandsnider (eds), Space, Time and Archaeological Landscapes, 91-112. New York: Plenum Press

Schulting, R.J. \& Richards, M.P. 2002. The west, the wild and the domesticated: the Mesolithic-Neolithic transition on the west coast of Scotland. European Journal of Archaeology 5(2), 147-189

Sheridan, A. 2010. The neolithisation of Britain and Ireland: The big picture. In B. Finlayson, and G. Warren (eds), Landscapes in Transition, 89-105. Oxford: Council for British Research in the Levant, Supplementary Series 8

Sheridan, A. \& Pétriquin, P. 2014. Constructing a narrative for the Neolithic of Britain and Ireland: the use of 'hard science' and archaeological reasoning. In A. Whittle, and P. Bickle (eds), Early Farmers: The view from Archaeology and Science, 369-90. Proceedings of the British Academy 198

Sheridan, A., Cook, G., Naysmith, P., Tripney, B., Dunbar, E., Hunter, F., Reich, D., Olalde, I., Armit, I., Boyle, A., Farrar, S., Ritchie, G., Mitchell, J., Bloxam, A., Romera, A. \& Herman, J. 2017. Radiocarbon dates associated with the Scottish History and Archaeology Department, National Museums Scotland, 2016/17. Discovery and Excavation in Scotland 18, 209-14

Sloan, D. 1988. Shell middens: a case for adaptive excavation techniques. Scottish Archaeological Review $5,38-40$

Smith, C. 2009. Animal bone from Port Lobh 1, Colonsay. Unpublished archive report, University of Glasgow

Stuiver, M. \& Braziunas, T.F. 1993. Modelling atmospheric ${ }^{14} \mathrm{C}$ influences and ${ }^{14} \mathrm{C}$ ages of marine samples to $10,000 \mathrm{BC}$. Radiocarbon 35, 137-89

Tavesz, M. \& Carter, J. 1980. Environmental relationships of shell form and structure of unionacean bivalves. In D. Rhoads (ed.) Skeletal Growth in Aquatic Organisms, 295-322. New York: Plenum Press

Van Neer, W., Löugas, L. \& Rijnsdorp, A.D. 1999. Reconstructing age distribution, season of capture and growth rate of fish from archaeological sites based on otoliths and vertebrae. International Journal of Osteoarchaeology 9, 116-30

Warren, G. 2007. Mesolithic myths. In Whittle, \& Cummings 2007, 311-28

Wheeler, A. \& Jones, A.K.J. 1989. Fishes. Cambridge: Cambridge Manuals in Archaeology

Whittle, A. \& Cummings, V. (eds). 2007. Going Over: the Mesolithic-Neolithic transition in north-west Europe. Proceedings of the British Academy 144

Whittle, A., Healy, F. \& Bayliss, A. 2011. Gathering Time: Dating the early Neolithic enclosures of southern Britain and Ireland. Oxford: Oxbow Books

Wicks, K. \& Mithen, S. 2014. The impact of the abrupt 8.2 $\mathrm{ka}$ cold event on the Mesolithic population of western Scotland: a Bayesian chronological analysis using 'activity events' as a population proxy. Journal of Archaeological Science 45, 240-69.

Wicks, K., Pirie, A. \& Mithen, S. 2014. Settlement patterns in the late Mesolithic of western Scotland: the implications of Bayesian analysis of radiocarbon dates and inter-site technological comparisons. Journal of Archaeological Science 41, 406-22

Wickham-Jones, C.R. 1993. A round bottomed vessel from a new archaeological site at Papadil, Rum. Glasgow Archaeological Journal 18, 73-5

Wickham-Jones, C.R, 2009. Them bones: midden sites as a defining character of the Scottish Mesolithic In S.B. McCartan, R. Schulting, G. Warren, and P. Woodman, (eds), Mesolithic Horizons, 478-84. Oxford: Oxbow Books

Wickham-Jones, C.R, Brown, M.M., Cowie, T.G., Gallagher, D.B. \& Ritchie, J.N.G. 1982. Excavations at Druim Arstail, Oronsay, 1911-12. Glasgow Archaeological Journal 9, 18-30

Winton, A 2018. Port Lobh Shell Midden: Employing shell measurements analysis and isotopic analysis in an investigation of seasonality. Unpublished MA dissertation, University of Glasgow

Woodman, P.C., Anderson, E. \& Finlay, N. 1999. Excavations at Ferriter's Cove 1983-1995: Last foragers, first farmers on the Dingle Peninsula. Bray: Wordwell 


\section{N. Finlay et al. REVISING SETTLEMENT MODELS, MESOLITHIC-NEOLITHIC TRANSITION, W. SCOTLAND}

Wright, D. 2006. Report on the Fire-cracked rock from Port Lobh, Colonsay. Unpublished archive report, University of Glasgow

Wright, D. 2007. 'The Shelly Knoll'. A macroscopic reappraisal of the lithic assemblages from the excavations at Cnoc Sligeach undertaken by W. Galloway 1884 and A. H. Bishop 1911-13. Unpublished MA dissertation, Glasgow University
Wright, P.J., Panfili, J. \& Morales-Nin, B. 2002a. Otoliths. In J. Panfili, H. Troadec, H. de Pontual, and P.J. Wright (eds), Manual of Fish Sclerochronology, 464. Paris: Ifremer_IRD co-edition

Wright, P.J., Woodroffe, D.A., Gibb, F.M. \& Gordon, J.D.M. $2002 \mathrm{~b}$. Verification of first annulus formation in the illicia and otoliths of white anglerfish, Lophius piscatorius using otolith microstructure. ICES Journal of Marine Science 59, $587-93$

\section{RÉSUMÉ}

L'heure est venue pour Oronsay: Révision des modèles d'occupation autour de la transition mésolithiquenéolithique dans l'Ecosse de l'ouest, Nouveaux témoignages de Port Lobh, Colonsay, de Nyree Finlay, Ruby Cerón-Carrasco, Rupert Housley, Jeremy Huggett, W. Graham Jardine, Susan Ramsay, Catherine Smith, Dene Wright, Julian Augley, et Peter J. Wright

Depuis plus de 120 années, les dépotoirs coquilliers de l'ouest de l'Ecosse et les séries de sites à ciel ouvert d'Oronsay ont été le centre dudébat des études sur le mésolithique européen. Cet article remet en question l'importance d'Oronsay à la lumière de résultats de prospections géophysiques et d'excavations test d'un original dépôt coquillier de patelles et bigorneaux daté de la fin du 5ème ou du début du 4ème millénaire av. J.-C., cal à Port Lobh, Colonsay qui offre de frais témoignages en faveur d'une réévaluation critique du rôle de Colonsay et des ressources côtières dans les modèles d'occupation des îles avant la transition mésolithique-néolithique. Des excavations test ont révélé un assemblage de mollusques marins dominé par les coquilles de patelles et de bigorneaux auxquels s'ajoutaient des crabes, des oursins, un assemblage d'arêtes composé essentiellement de Gadidae, des os d'oiseaux et de mamimfères identifiables, des restes de macroplantes carbonisées et de la pierre ponce ainsi qu'un assemblage lithique bipolaire et de grossiers outils en pierre. D'innovantes études du caractère saisonnier de minces sections d'otolithe de colin indiquent des pratiques de pêche hivernale liées aux marées. Il est possible de discerner au moins deux épisodes d'activité datant de la fin du 5ème millénaire av. J.-C. cal. Le dépôt pourrait représenter un petit nombre d'assemblages déposés rapidement ou peut-être le résultat d'événements stochastiques dans un cadre temporel plus étendu. Nous argumentons que nous avons besoin de sujets de recherches alternatifs pour faire avancer ces débats de longue durée autour d'une mobilité saisonnière entre les îles versus un sédentarisme de chaque île, qui regardent au-delà de Colonsay pour mieux comprendre les schémas d'occupation du néolithique tardif et la formation et la date des dépôts de Colonsay. Nous proposons différentes sratégies méthodologiques pour faciliter l'identification de sites contemporains en utilisant des techniques géophysiques et des signatures technologiques lithiques.

\section{ZUSSAMENFASSUNG}

Calling Time auf Oronsay: Eine Revision von Siedlungsmodellen zum Übergang vom Mesolithikum zum Neolithikum in Westschottland. Neue Erkenntnisse aus Port Lobh, Colonsay, von Nyree Finlay, Ruby CerónCarrasco, Rupert Housley, Jeremy Huggett, W. Graham Jardine, Susan Ramsay, Catherine Smith, Dene Wright, Julian Augley, und Peter J. Wright

Seit mehr als 120 Jahren bilden die Muschelhaufen in Westschottland und eine Reihe von Freilandfundstellen auf Oronsay einen Diskussionsschwerpunkt in Untersuchungen zum europäischen Mesolithikum. Dieser Beitrag erörtert die Bedeutung von Oronsay mit Blick auf die aktuellen Erkenntnisse aus geophysikalischer Prospektion und Testgrabung eines neuen Muschelhaufens aus Napfschnecken und Strandschnecken bei Port Lobh, Colonsay, der ins späte 5. oder den Beginn des 4. Jahrtausends cal BC datiert wird und der neue Aufschlüsse liefert, anhand derer die Rolle von Oronsay und von küstennahen Ressourcen in Modellen der Besiedlung von Inseln diskutiert werden können, über den Übergang von Mesolithikum zu Neolithikum hinaus. Bei den Testgrabungen wurden Meeresmollusken geborgen, die von Gehäusen von Napf- und Strandschnecken dominiert werden, zusammen mit Krabbe, Seeigel, einer Anzahl von Fischknochen - vor allem Gadidae 
(Dorsche) - sowie einigen Vogel- und Säugetierknochen, verkohlten Makropflanzenreste, Bimsstein, außerdem bipolaren lithische Funden und groben Steingeräten. Neuartige Untersuchungen zur Saisonalität anhand von Dünnschliffen von Otolithen von Seelachs zeugen von Gezeitenfischerei im Winter. Mindestens zwei Nutzungszeiträume können unterschieden werden, die ins späte 5. Jahrtausend cal BC datieren. Der Muschelhaufen könnte das Resultat einer kleinen Zahl schnell aufeinander folgender Ablagerungen sein oder von stochastischen Ereignissen innerhalb eines längeren Zeitrahmens. Wir sprechen uns dafür aus, dass alternative Forschungsfragen benötigt werden, um langlebige Debatten zu entwickeln zum Verhältnis von saisonaler Mobilität zwischen Inseln zu insularer Sesshaftigkeit, die über Oronsay hinausgehen, um ein besseres Verständnis der mesolithischen Nutzungsmuster und der Formierung und Datierung der Muschelhaufen von Oronsay zu erlangen. Wir schlagen alternative methodologische Strategien vor, die helfen sollen, zeitgleiche Fundplätze zu identifizieren auf der Basis von geophysikalischen Techniken und technologischen Signaturen der Lithik.

\section{RESUMEN}

Considerando el tiempo en Oronsay: revisando los modelos de asentamiento en torno a la transición MesolíticoNeolítico en el oeste de Escocia, nuevas evidencias de Port Lobh, Colonsay, por Nyree Finlay, Ruby CerónCarrasco, Rupert Housley, Jeremy Huggett, W. Graham Jardine, Susan Ramsay, Catherine Smith, Dene Wright, Julian Augley, y Peter J. Wright

Durante 120 años, los concheros del oeste de Escocia y una serie de yacimientos al aire libre en Oronsay han sido objeto de debate en los estudios sobre Mesolítico europeo. Este artículo presenta la importancia del yacimiento de Oronsay en función de los resultados obtenidos en la prospección geofísica y la excavación de un nuevo conchero de lapas y bígaros datado a finales del V e inicios del IV milenio cal BC en Port Lobh, Colonsay, y que ofrece nuevas evidencias para evaluar críticamente el papel de Oronsay y los recursos costeros en los modelos de asentamiento isleños en la transición Mesolítico-Neolítico. En los sondeos arqueológicos realizados, se ha recuperado un importante conjunto de moluscos marinos dominado por lapas y bígaros junto con restos de cangrejo, erizo de mar, restos de peces con predominio de Gadidae, algunos huesos de pájaro identificables, huesos de mamíferos, macrorrestos vegetales carbonizados y restos de piedra pómez, junto a un conjunto de restos líticos de talla bipolar y otros restos de utillaje lítico. Los novedosos estudios de estacionalidad de los oolitos de abadejo en lámina delgada sugieren prácticas de pesca durante el invierno. Se pueden discernir, al menos, dos episodios datados a finales del V milenio cal BC. El conchero podría representar un reducido número de conjuntos rápidamente depositados o quizá el resultado de eventos estocásticos dentro de un período temporal más amplio. El planteamiento de preguntas alternativas de investigación es necesario para avanzar en los debates sobre la movilidad estacional entre los espacios insulares frente a la sedentarización insular que se observa más allá de Oronsay, con el objetivo de facilitar la comprensión de los patrones de ocupación del Mesolítico final y la formación y cronología de los concheros de Oronsay. Proponemos una estrategia metodológica alternativa para ayudar a la identificación de sitios coetáneos utilizando técnicas geofísicas y los conjuntos líticos característicos. 